Prepared in cooperation with the National Park Service

\title{
Stream Classification and Gravel-Bar Inventory for Buffalo National River and Ozark National Scenic Riverways
}

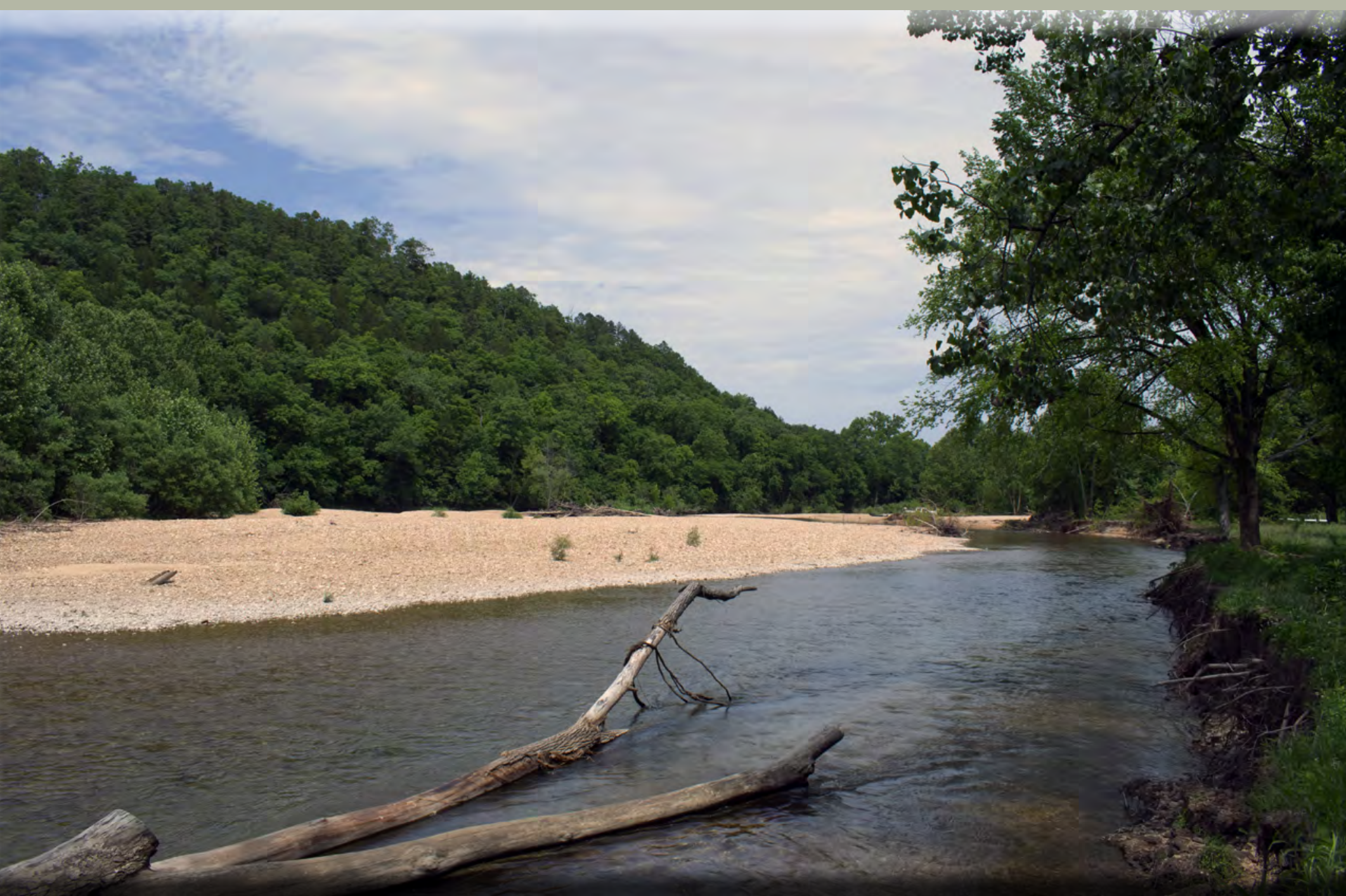

Scientific Investigations Report 2020-5122

U.S. Department of the Interior

U.S. Geological Survey 
Cover: Current River, Missouri, June 1, 2017. Photograph taken by Brian W. Anderson. 


\section{Stream Classification and Gravel-Bar Inventory for Buffalo National River and Ozark National Scenic Riverways}

By Susannah O. Erwin, Robert B. Jacobson, and Jabari C. Jones

Prepared in cooperation with the National Park Service

Scientific Investigations Report 2020-5122 


\section{U.S. Geological Survey, Reston, Virginia: 2021}

For more information on the USGS - the Federal source for science about the Earth, its natural and living resources, natural hazards, and the environment—visit https://www.usgs.gov or call 1-888-ASK-USGS.

For an overview of USGS information products, including maps, imagery, and publications, visit https://store.usgs.gov/.

Any use of trade, firm, or product names is for descriptive purposes only and does not imply endorsement by the U.S. Government.

Although this information product, for the most part, is in the public domain, it also may contain copyrighted materials as noted in the text. Permission to reproduce copyrighted items must be secured from the copyright owner.

Suggested citation:

Erwin, S.0., Jacobson, R.B., and Jones, J.C., 2021, Stream classification and gravel-bar inventory for Buffalo National River and Ozark National Scenic Riverways: U.S. Geological Survey Scientific Investigations Report 2020-5122, 42 p., https://doi.org/10.3133/sir20205122.

Associated data for this publication:

Erwin, S.0., 2020, Stream classification and gravel bar inventory for Buffalo National River and Ozark National Scenic Riverways, 1982-2014: U.S. Geological Survey data release, https://doi.org/10.5066/P9ZGVTOP.

ISSN 2328-0328 (online) 


\section{Acknowledgments}

Funding for this project was provided by U.S. Geological Survey and National Park Service Natural Resource Preservation Program. We thank Victoria Grant and Mike Gossett of Ozark National Scenic Riverways and Faron Usrey, Shawn Hodges, and Chuck Bitting with the Buffalo National River for providing support and expertise for this project.

Numerous staff at the U.S. Geological Survey contributed to data collection and analysis, including Brian Anderson, Eric Allen, Chris Holly, Ed Bulliner, and J.C. Nelson. 


\section{Contents}

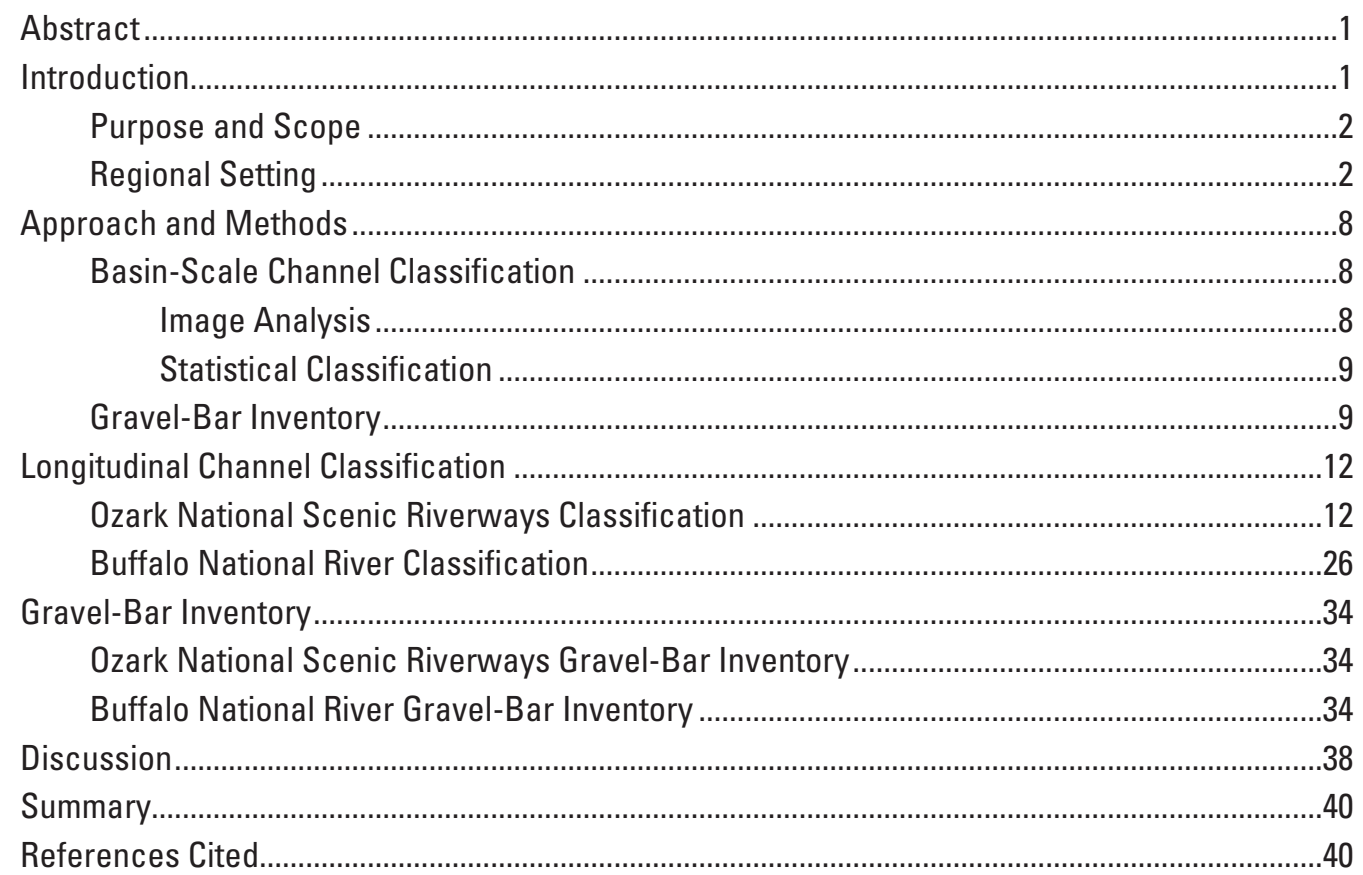

\section{Figures}

1. Map of Ozark Plateaus Physiographic Province, showing location of the Ozark National Scenic Riverways and Buffalo National River. .3

2. Map of Ozark National Scenic Riverways in southern Missouri........................................4

3. Map of Buffalo National River in northern Arkansas .........................................................

4. Geologic map of Ozark National Scenic Riverways in southern Missouri .........................6

5. Geologic map of Buffalo National River in northern Arkansas..........................................

6. Daily discharge on the Current River as measured at U.S. Geological Survey

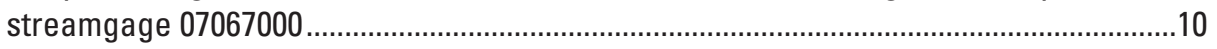

7. Daily discharge on the Buffalo River as measured at U.S. Geological Survey

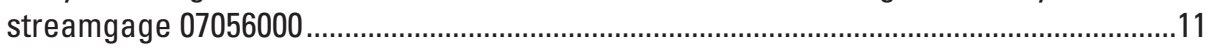

8. Longitudinal geomorphic characteristics for the Current River, 2010 ............................13

9. Bivariate scatter and frequency plots of nine geomorphic variables determined from analysis of imagery for the Current River, 2010 ..................................................14

10. Principal component analysis of standardized geomorphic variables for the Current River 15

11. Loading of geomorphic variables on each principal component for the Current River. .16

12. Dendrogram of Current River geomorphic characteristics, with trimming distances identified at two, three, and five clusters... 
13. Results of Current River hierarchical clustering ..........................................................17

14. Results of Current River hierarchical clustering for five clusters .................................18

15. Hierarchical clustering results for the Current River .................................................19

16. Longitudinal geomorphic characteristics for the Jacks Fork, 2010 ...............................20

17. Bivariate scatter and frequency plots of nine geomorphic variables determined

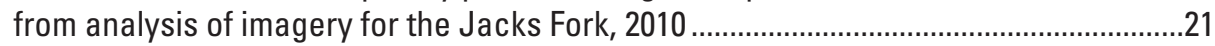

18. Principal component analysis of standardized geomorphic variables for the

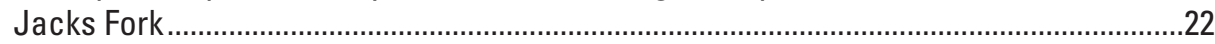

19. Loading of geomorphic variables on each principal component for the Jacks Fork......23

20. Dendrogram of Jacks Fork geomorphic characteristics, with trimming

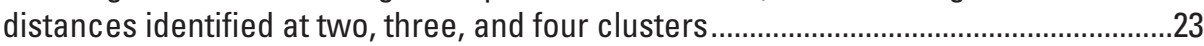

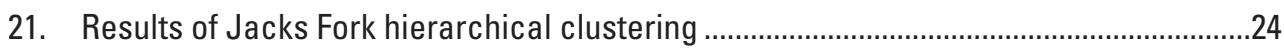

22. Results of Jacks Fork hierarchical clustering for four clusters .....................................25

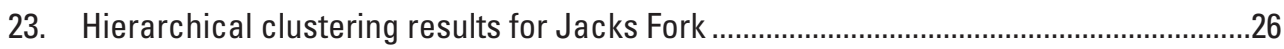

24. Longitudinal geomorphic characteristics for the Buffalo River, 2010 ...........................27

25. Bivariate scatter and frequency plots of nine geomorphic variables determined from analysis of imagery for the Buffalo River, 2010 ...................................................28

26. Principal component analysis of standardized geomorphic variables for the Buffalo River

27. Loading of geomorphic variables on each principal component for the Buffalo River

28. Dendrogram of Buffalo River geomorphic characteristics, with trimming distances identified at two, three, and five clusters.........................................................

29. Results of Buffalo River hierarchical clustering.........................................................31

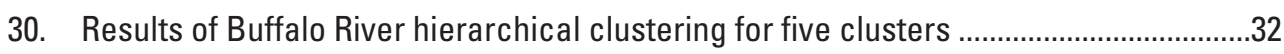

31. Hierarchical clustering results for the Buffalo River....................................................3

32. Normalized gravel bar area along the Current River as measured using five series of aerial images...................................................................................................3

33. Normalized gravel-bar area along the Current River for progressive pairs of

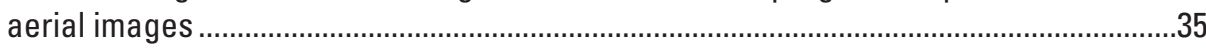

34. Normalized gravel-bar area along the Jacks Fork as measured using four

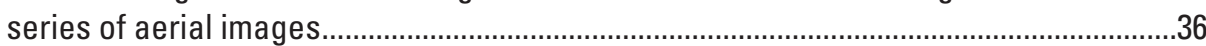

35. Normalized gravel-bar area along the Jacks Fork for progressive pairs of aerial images .................................................................................................................

36. Normalized gravel-bar area along the Buffalo River as measured using five series of aerial images.

37. Normalized gravel-bar area along the Buffalo River for progressive pairs of aerial images.

\section{Tables}

1. Geomorphic variable name, abbreviation, and definition ...................................................

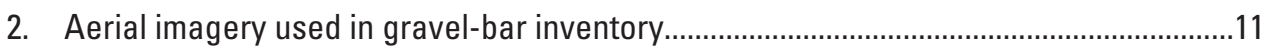




\section{Conversion Factors}

International System of Units to U.S. customary units

\begin{tabular}{lcl}
\hline \multicolumn{1}{c}{ Multiply } & By & \multicolumn{1}{c}{ To obtain } \\
\hline & Length & \\
\hline meter $(\mathrm{m})$ & 3.281 & foot $(\mathrm{ft})$ \\
kilometer $(\mathrm{km})$ & 0.6214 & mile $(\mathrm{mi})$ \\
\hline & Area & \\
\hline square meter $\left(\mathrm{m}^{2}\right)$ & 10.76 & square foot $\left(\mathrm{ft}^{2}\right)$ \\
square kilometer $\left(\mathrm{km}^{2}\right)$ & 0.3861 & square mile $\left(\mathrm{mi}^{2}\right)$ \\
\hline & Flow rate & \\
\hline cubic meter per second $\left(\mathrm{m}^{3} / \mathrm{s}\right)$ & 70.07 & acre-foot per day $($ acre- $\mathrm{ft} / \mathrm{d})$ \\
cubic meter per second $\left(\mathrm{m}^{3} / \mathrm{s}\right)$ & 35.31 & cubic foot per second $(\mathrm{ft} 3 / \mathrm{s})$ \\
\hline
\end{tabular}

\section{Datum}

Vertical coordinate information is referenced to the North American Vertical Datum of 1988 (NAVD 88).

Horizontal coordinate information is referenced to the North American Datum of 1983 (NAD 83).

\section{Abbreviations}

$\begin{array}{ll}\text { BUFF } & \text { Buffalo National River } \\ \text { DEM } & \text { digital elevation model } \\ \text { GCP } & \text { ground control point } \\ \text { GIS } & \text { geographic information system } \\ \text { GNSS } & \text { global navigation satellite system } \\ \text { lidar } & \text { light detection and ranging } \\ \text { NAIP } & \text { National Agriculture Imagery Program } \\ \text { NPS } & \text { National Park Service } \\ \text { OZAR } & \text { Ozark National Scenic Riverways } \\ \text { PCA } & \text { principal component analysis } \\ \text { RTK } & \text { real-time kinematic } \\ \text { USDA } & \text { U.S. Department of Agriculture } \\ \text { USGS } & \text { U.S. Geological Survey }\end{array}$




\title{
Stream Classification and Gravel-Bar Inventory for Buffalo National River and Ozark National Scenic Riverways
}

\author{
By Susannah 0. Erwin, Robert B. Jacobson, and Jabari C. Jones
}

\section{Abstract}

The data summarized in this report provide a baseline characterization of the physical attributes of the riverine ecosystems in two landscapes managed by the National Park Service-Ozark National Scenic Riverways, Missouri, and Buffalo National River, Arkansas - to inform understanding and management of aquatic habitat. The study utilized a basin-scale approach and consisted of two components: a basin-scale channel classification and a longitudinal inventory of gravel bars. We evaluated the Jacks Fork and Current River in Ozark National Scenic Riverways and the main stem Buffalo River in Buffalo National River. The primary objective of the study was to characterize geomorphic patterns that affect channel stability and rates of geomorphic change in both national park units. Findings may be used to inform understanding of the distribution and availability of aquatic habitat.

For the basin-scale channel classification, we performed exploratory statistical analyses using nine geomorphic variables (channel width, standard deviation in channel width, valley width, distance to valley wall, confinement, bar area, bluff area, braid index, and sinuosity). Each metric was quantified along the length of the river system at 200-meter intervals. We then performed a cluster analysis for each river using a subset of variables, resulting in 2 to 5 distinct geomorphic classes depending on criteria used for determining number of clusters. Longitudinal patterns in clusters vary for each river system but reflect a combination of landscape factors including valley width, influence of tributaries, and lithology, which affect channel stability and aquatic habitat.

We developed a longitudinal inventory of gravel bars by quantifying the area of gravel bars from a series of imagery in each park. In Ozark National Scenic Riverways we analyzed five time periods, with the earliest being 1992 and most recent being 2014. In Buffalo National River, we also analyzed five series of aerial imagery, ranging from 1982 to 2013 . The analysis indicated a general decrease in gravel storage in upstream reaches of each river evaluated, accompanied by a general increase in storage farther downstream. Local patterns in gravel-bar area are associated with longitudinal patterns in geomorphic setting, such as valley geometry and channel width, that affect depositional patterns and sediment storage at the reach scale.

\section{Introduction}

In 1964, Ozark National Scenic Riverways (OZAR) was the first National Park Service (NPS) unit specifically set aside to celebrate the natural heritage of the river experience. The enabling legislation for the park was utilized as the template for the subsequent Wild and Scenic Rivers Act. In 1972, the Buffalo River was the first national river to be designated in the United States. The defining characteristic of these two parks is their unique natural riverine heritage. Native fish and invertebrates, including crayfish and mussels, are among the aquatic biota highlighted for contributing to the diversity of OZAR and Buffalo National River (BUFF).

In BUFF and OZAR, management and restoration planning are complicated by channel instability, some of which has been attributed to historic land-use patterns (Jacobson, 1995; Jacobson and Primm, 1997; Panfil and Jacobson, 2001). Gravel-bed rivers, such as the Jacks Fork, Current, and Buffalo Rivers, are naturally dynamic; high flows typically mobilize bed material on an annual basis, thus creating gravel bars, promoting bank erosion, and driving natural processes such as channel migration. A key challenge for management decisions is to determine how much dynamism is outside the natural range of variability and therefore constitutes a need for mitigation. 
Watershed perturbations can alter the rate of sediment supply and change the associated geomorphic processes in streams and rivers. Such appears to be the case in the Ozark region of southern Missouri and northern Arkansas, where historical, stratigraphic, and geomorphic evidence indicates that (1) Ozark rivers have a naturally high gravel flux because of the geologic framework and (2) wide-spread, low-intensity land use in the early 1900 s resulted in elevated rates of coarse sediment delivery to rivers throughout the region (Jacobson and Primm, 1997; Jacobson, 2004). Converging lines of evidence led these authors to conclude that the greatest influence on coarse sediment delivery was riparian land use, which led to destabilization of streambanks and low-order tributaries, followed by downstream transport. Prior research indicates that the gravel is migrating through channel networks in the form of a series of sediment waves, with the implication that the magnitude of waves relates in part to excess gravel delivered to the rivers through land-use practices. Local channel patterns regulate propagation of these gravel waves through the river networks: in relatively straight reaches ${ }^{1}$ the gravel is routed downstream efficiently, whereas naturally occurring disturbance reaches exhibit a more complex response (Jacobson, 1995; Jacobson and Gran, 1999). In reaches predisposed to greater channel activity, movement of sediment waves through the channel network may promote increased bed mobility and elevated rates of channel migration.

Elevated river bed mobility and channel migration across the Ozark Plateaus are thought to be driven by historical and present-day land-use patterns and reflect increased rates of coarse sediment delivery to regional rivers (Jacobson and Primm, 1997; Martin and Pavlowsky, 2011; Owen and others, 2011). Long-lived aquatic benthic species with limited locomotion or small home ranges may be especially vulnerable to accelerated gravel movement at the site-specific scale (Hornbach, 2001; Strayer, 2008). Freshwater mussels are well known as taxa particularly sensitive to changing aquatic habitat and water-quality conditions. With limited locomotion, freshwater mussels are poorly suited to survive extreme habitat disturbances, such as rapidly shifting gravel beds.

Together, the Jacks Fork, Current, and Buffalo Rivers constitute more than 430 kilometers $(\mathrm{km})$ of protected river within BUFF and OZAR. Patterns in geomorphic control, channel instability, and sedimentation affect the distribution of aquatic habitats within the Jacks Fork, Current, and Buffalo Rivers. Understanding the physical template that defines these rivers is critical to inform restoration and refugia programs for aquatic species of interest in both parks. The study was motivated in part by a need to better understand factors affecting habitat for native freshwater mussels, including

\footnotetext{
${ }^{1}$ We use "reaches" to define multiples of cross-over-bend or riffle-pool sequences characterized by similar channel morphology (Frissell and others, 1986).
}

some rare and threatened species, that are present in BUFF and OZAR. Species recovery plans require tools to provide a predictive understanding of which areas are suitable for restoration activities, such as stocking of propagated mussels. The research described here was planned through close collaboration with NPS partners at BUFF and OZAR.

\section{Purpose and Scope}

The primary objective of this study was to characterize geomorphic patterns that affect channel stability and rates of geomorphic change in the OZAR and BUFF. The data summarized here provide a baseline characterization of the physical attributes of the riverine ecosystems in two national parks to inform understanding and management of aquatic habitat. Resource management and successful restoration would benefit from understanding physical habitat dynamics in riverine environments and how the distribution of this habitat will evolve as waves of coarse sediment propagate through the channel networks and potentially interact with other sources of stress such as water quality or direct human disturbance.

\section{Regional Setting}

The Ozark Plateaus Physiographic Province (hereafter referred to as "the Ozarks") is a rugged, montane region occupying much of southern Missouri and northern Arkansas (fig. 1). The region consists of four distinct physiographic provinces: the St. Francois Mountains, Salem Plateau, Springfield Plateau, and the Boston Mountains. The St. Francois Mountains consist of Precambrian rhyolites and granites that form the crest of the Ozark dome (Sims and others, 1987). The Salem Plateau is a region of rolling uplands formed by cherty dolomites and limestones of Ordovician age. The Springfield Plateau consists of gently dipping Mississippian carbonates, with abundant chert. The Boston Mountains are highly dissected, with the greatest relief in the Ozarks, and are formed from sandstones, shales, and carbonates of Ordovician to Mississippian age (Bretz, 1965).

The Ozarks are home to two national parks centered on river landscapes: the OZAR (fig. 2) and the BUFF (fig. 3). OZAR was established in 1964 as the first national park to protect a river system and includes $215 \mathrm{~km}$ of the Jacks Fork and Current Rivers in southeast Missouri. The drainage basins for the Jacks Fork and Current River in OZAR are located within the Salem Plateau. BUFF in northern Arkansas was established as the United States' first national river in 1972 to preserve the lower $217 \mathrm{~km}$ of the Buffalo River in a scenic and free-flowing condition. The Buffalo River straddles the Springfield Plateau and Boston Mountains across much of the BUFF and flows through the Salem Plateau at the northeast corner of the park. 


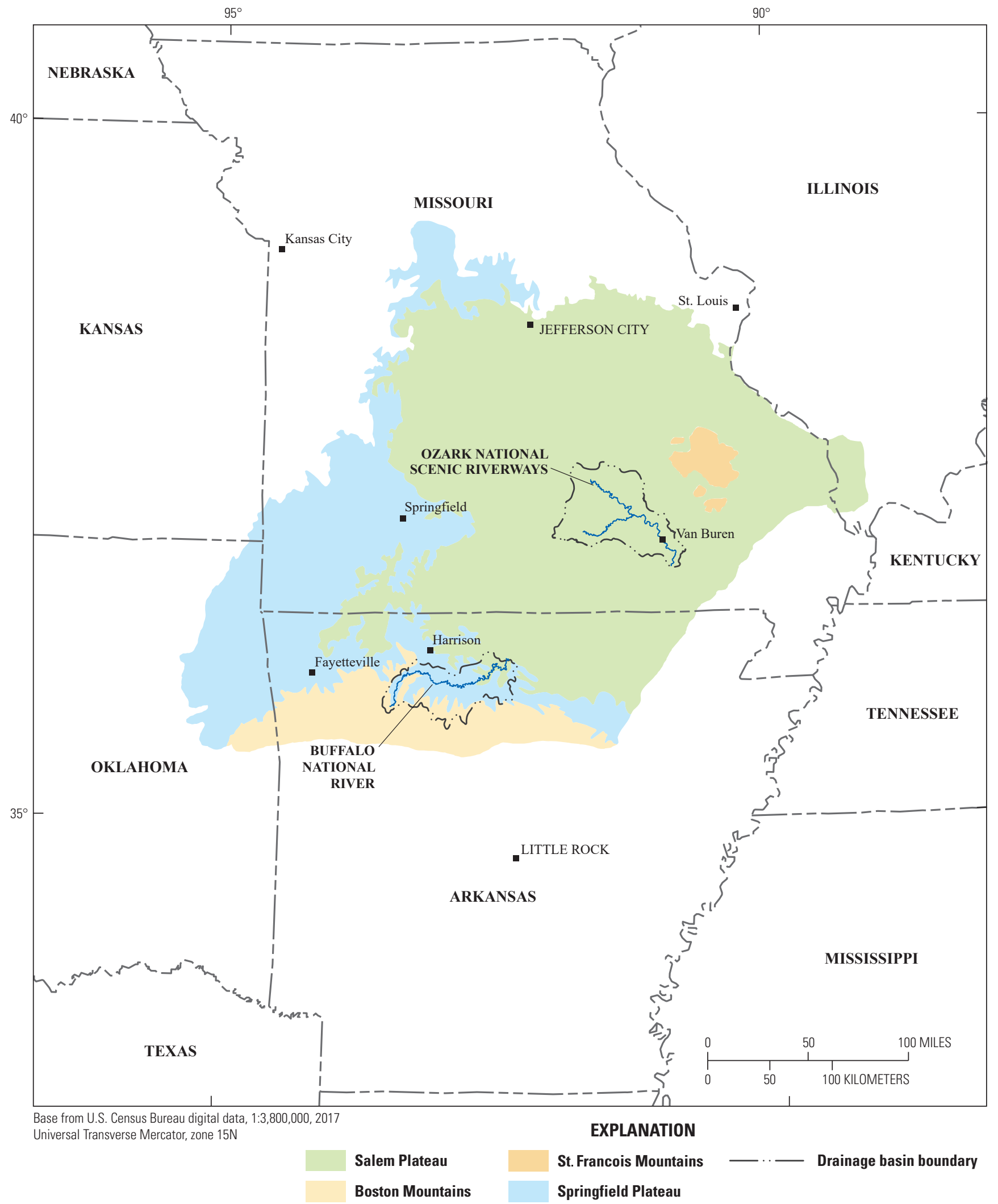

Figure 1. Map of Ozark Plateaus Physiographic Province, showing location of the Ozark National Scenic Riverways and Buffalo National River. 


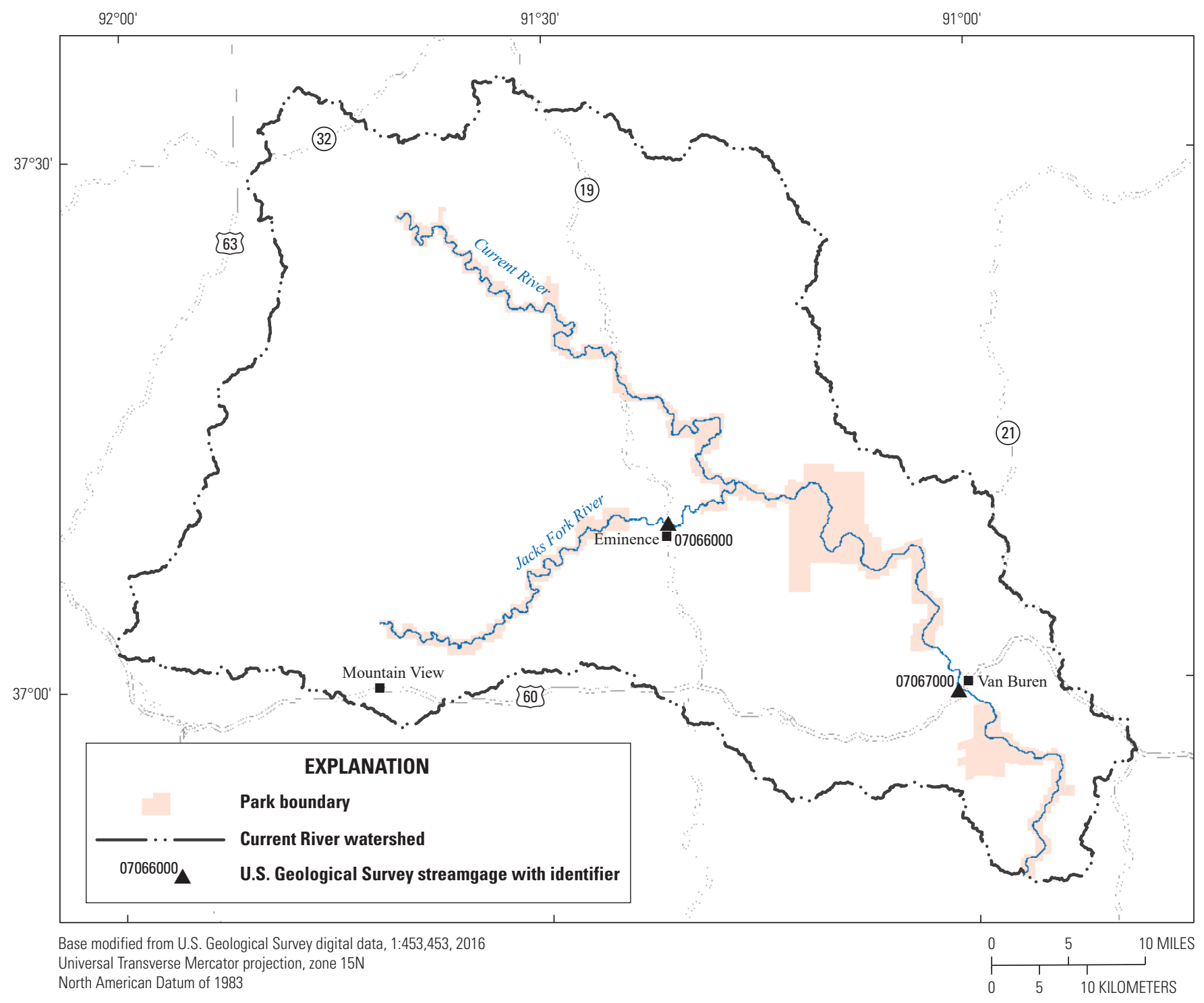

Figure 2. Map of Ozark National Scenic Riverways in southern Missouri. 


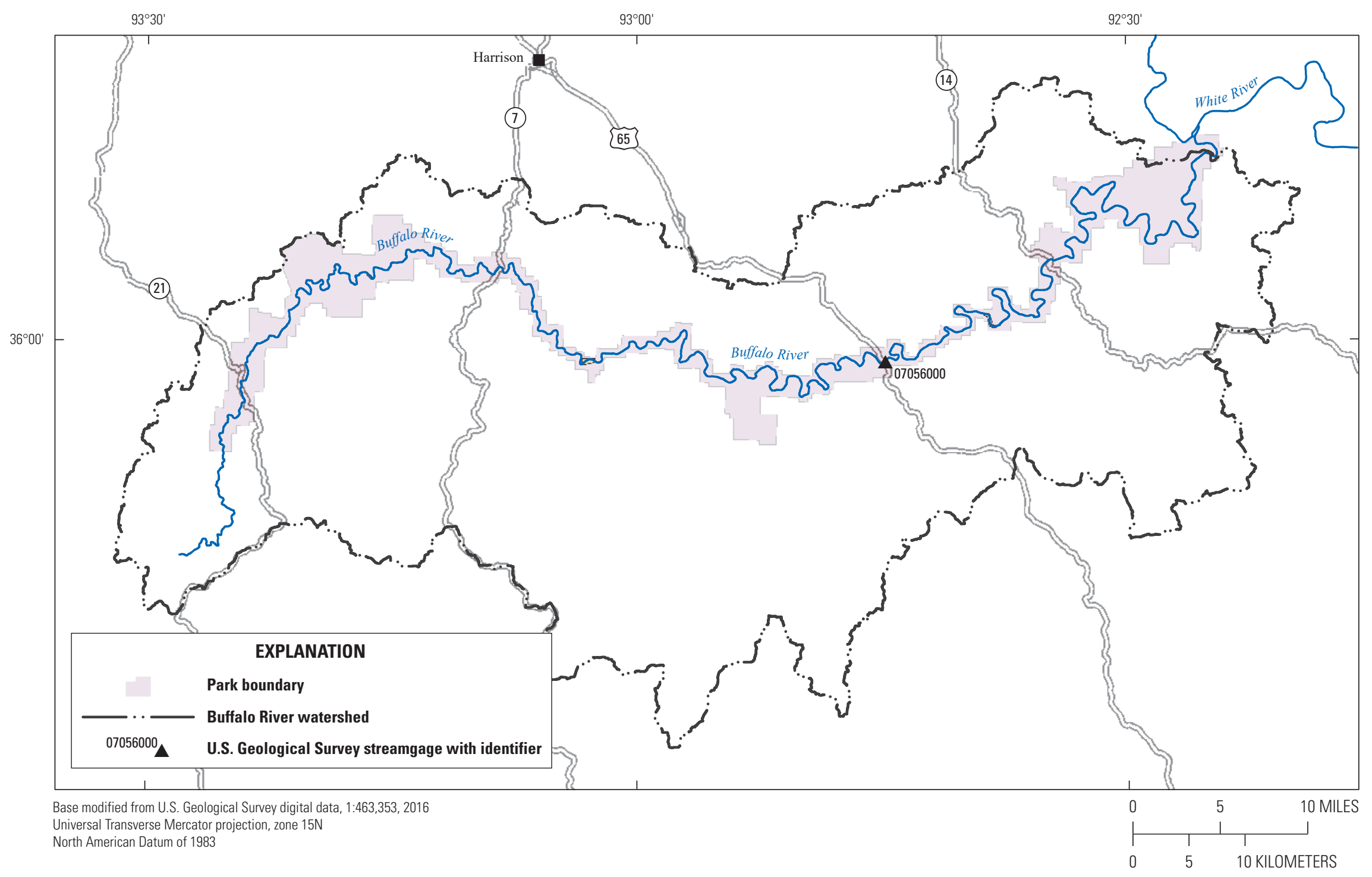

Figure 3. Map of Buffalo National River in northern Arkansas. 
Carbonate-rich bedrock contributes to a karst drainage system that underlies much of the Ozarks, producing springs, sinkholes, and caves that affect local hydrology (fig. 4). Springs contribute a substantial portion of the base flow of the Jacks Fork and Current Rivers. A lower proportion of the base flow in the Buffalo River is provided by springs, and as a result, water temperatures are generally warmer (Panfil and Jacobson, 2001). The Buffalo River is a flashy system owing to low base flow, high relief in the watershed, and the presence of relatively impermeable rock and soils in the drainage basin (fig. 5).

Land-use changes beginning in the mid-19th century affected rates of sediment dynamics that influence geomorphology of Ozark streams in OZAR and BUFF. Clearing of valley bottoms for agriculture began in the mid-19th century with the arrival of European settlers. Commercial timber production dominated the region from the 1870 s to the 1920 s, with a concurrent increase in human, cattle, and hog populations as forests were cleared (Jacobson and Primm, 1997; Jacobson and Pugh, 1997). Isolated areas in the Ozarks have been subject to intensive mining operations for lead, zinc, and barite, creating erodible mine-tailings. Row-crop agriculture was implemented in the mid-20th century but was largely unsuccessful owing to shallow, steep, and infertile soils. Present-day land use is a mosaic of forests and grazing land for cattle, with timber operations active in forested areas. Recreation is also a major economic activity in the region, with more than 2.5 million visitors to BUFF and OZAR in 2015 (National Park Service, 2020).

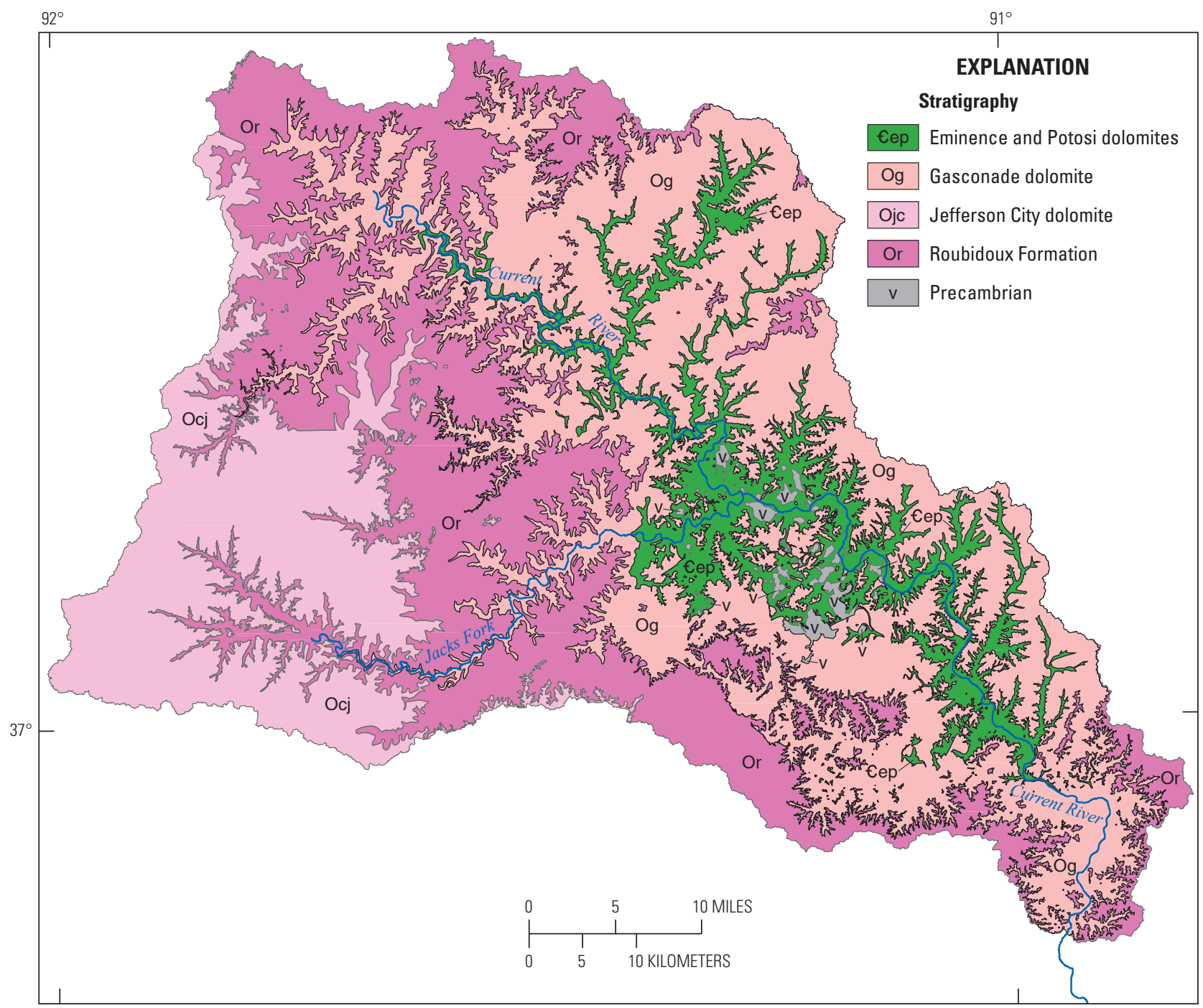

Base from U.S. Geological Survey digital data, 1:100,000, various dates North American Datum of 1983

Universal Transverse Mercator, zone 15N

Figure 4. Geologic map of Ozark National Scenic Riverways in southern Missouri. 
A series of reports in the 1990s and early 2000s, published as part of the Ozarks Stream Geomorphology Project, concluded that the clearing of valley bottoms and forests in the late 1800s and early 1900s led to an increase in gravel delivery to low-order Ozark streams (Jacobson, 1995; Jacobson and Primm, 1997; Jacobson and Pugh, 1997; Jacobson and Gran, 1999; Jacobson and others, 2001). These land-use changes led to the upstream extension of drainages and the widening of low-order tributaries, which introduced new sediment supplies to streams. As sediment propagated through drainage networks, it formed wave-like accumulations leading to increased channel instability, bank erosion, and the degradation of aquatic habitat (Jacobson and Gran, 1999). This model has been confirmed in general by subsequent research although site-specific variations exist (Martin and Pavlowsky, 2011; Owen and others, 2011; Martin and others, 2016). Similar conceptual and quantitative models of sediment movement through watersheds have been proposed for other landscapes (Czuba and Foufoula-Georgiou, 2015).

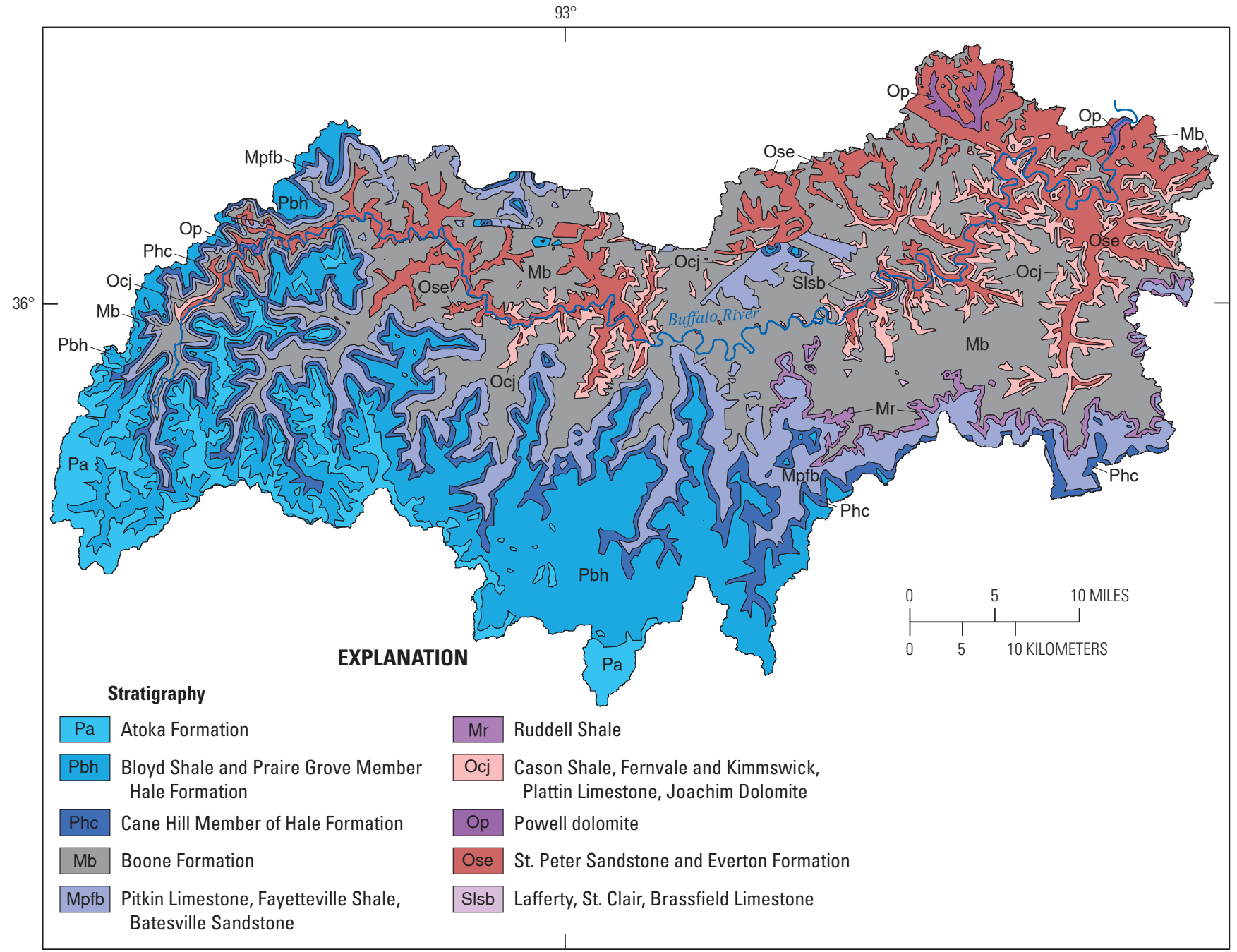

Base from U.S. Geological Survey digital data, various scales, various dates North American Datum of 1983

Universal Transverse Mercator zone 15N

Figure 5. Geologic map of Buffalo National River in northern Arkansas. 


\section{Approach and Methods}

The study used a basin-scale approach to update understanding of patterns in sediment storage and factors contributing to geomorphic instability within the Jacks Fork, Current, and Buffalo Rivers. The study consisted of two components: (1) a basin-scale channel classification (geomorphic metrics) and (2) a longitudinal inventory of gravel bars.

\section{Basin-Scale Channel Classification}

The first component of the study consisted of statistical analysis of channel geomorphic features, using remotely sensed imagery, aimed at identifying geomorphic patterns at the scale of each river basin. Metrics derived from imagery were used to characterize patterns in geomorphic attributes along the main stem Jacks Fork, Current, and Buffalo Rivers. Whereas some approaches to river classification impose a predefined classification scheme on a river system, we opted to employ multivariate statistical techniques to identify naturally occurring classes, or clusters (Jacobson and others, 2010; Elliott and Jacobson, 2014; Roux and others, 2015; Clubb and others, 2019).

\section{Image Analysis}

Basin-scale geomorphic attributes were analyzed using 1-meter (m) resolution natural-color orthophotography from 2010. Imagery was acquired through the U.S. Department of Agriculture (USDA) National Agriculture Imagery Program (NAIP). In BUFF, dates for aerial photography acquisition ranged from June 27 to September 12. During this time, discharge ranged from 2.0 to 23.5 cubic meters per second $\left(\mathrm{m}^{3} / \mathrm{s}\right)$ (as measured at U.S. Geological Survey [USGS] streamgage 07056000, Buffalo River at St. Joe, Arkansas). In OZAR, acquisition of aerial imagery spanned two dates, June 30 and July 1, and discharge ranged from 32.8 to $33.7 \mathrm{~m} 3 / \mathrm{s}$ (as measured at USGS streamgage 07067000 , Current River at Van Buren, Missouri). Analysis of imagery and computation of imagery-derived metrics was performed in a geographic information system (GIS) using the ArcGIS software package (v. 10; Esri, Redlands, California).

Geomorphic metrics used in the classification described here and in the "Gravel-Bar Inventory" section were calculated at regularly spaced address points defined every $200 \mathrm{~m}$ along the channel centerline. Along the longitudinal address system, we calculated the following geomorphic metrics: active channel width, valley width, distance to valley wall, channel confinement, braid index, gravel-bar area, bluff area, and sinuosity (table 1).

The active channel in 2010 was digitized as a polyline at a scale ranging from 1:1000 to 1:1500. The edge of the active channel was defined where the banks were visible; the active channel was delineated to include unvegetated and sparsely vegetated (less than 40 percent cover) gravel bars. Defining the active channel based on the presence of vegetation eliminates inconsistencies that arise from varying discharge among photographs (Tiegs and Pohl, 2005). Where trees were present on the banks of the channel, the line was drawn to capture approximately one-third of the crown of the trees to account for overhang. The digitized boundaries of the active channel in each river were used to generate a channel centerline for each river by computing the midpoint between the right and left banks. The resulting centerline was used to establish the address point system.

Table 1. Geomorphic variable name, abbreviation, and definition.

\begin{tabular}{|c|c|c|}
\hline Variable name & Abbreviation & Definition \\
\hline Active channel width & CH WIDTH & Distance of active channel, in meters, as measured perpendicular to channel centerline. \\
\hline Valley width & VA WIDTH & Distance between valley walls, in meters, as measured perpendicular to channel centerline. \\
\hline Channel confinement & CONFINE & Ratio between valley width and active channel width. \\
\hline Braid index & BRAID & Number of channels (water polygons) located at each transect. \\
\hline Bluff area & BLUFF & Area of bluff as measured within a search radius from address point. \\
\hline Sinuosity & S 800 & $\begin{array}{l}\text { Ratio of distance along channel centerline to straight-line distance between endpoints measured } \\
\text { over a distance of } 800 \text { meters. }\end{array}$ \\
\hline
\end{tabular}


The valley boundaries were delineated for each park using the best available elevation data and, where possible, supplemental geologic or soils maps. The Buffalo River valley was delineated using a 3-m digital elevation model (DEM) and hillshade model derived from light detection and ranging (lidar) flown in 2011 (U.S. Geological Survey, 2018). The valley bottom was defined as the flood plain and adjacent low-lying terraces. Terraces were assumed to be part of the alluvial valley if they were flat to slightly sloping and if the slope had an inflection point between it and the slope of the nearest topographic high point. The valleys of tributaries were generally cut off at their mouth, except where fluvial features associated with the Buffalo River main stem extended into the tributary valley. Features interpreted as alluvial fans were excluded from the valley of the main stem river.

The criteria for delineating the valleys of the Current River and Jacks Fork were the same as for the Buffalo River valley; however, lidar was unavailable for OZAR at the time of the analysis. The best available elevation data for the OZAR was the USGS 10-m DEM available online from The National Map (U.S. Geological Survey, 2018). These relatively coarse elevation data were supplemented with 2010 NAIP imagery and an unpublished soils map, the latter of which was not available for the Buffalo River. Soils mapped as flood plain and Holocene terraces were identified as valley bottom, whereas toe slopes and upland areas were not.

Valley width and channel width were determined at address points as measured along transects generated perpendicular to the channel centerline. We quantified channel confinement as the ratio between valley width and channel width. Braid index was defined as the number of channels at each address point, calculated by determining the number of times a transect drawn perpendicular to the main channel flow intersected a water polygon. Total bar area associated with each address point was determined using a $125-\mathrm{m}$ search radius; methods are described in the "Gravel-Bar Inventory" section of the methods. Bluffs were also identified within the search radius and for the purpose of this analysis were defined as areas with a slope greater than 60 degrees.

Sinuosity was calculated as the ratio between distance as measured along the channel centerline and the straight-line distance between endpoints for the measurement reach. Because sinuosity can vary substantially depending on the scale of measurement, we calculated sinuosity for a range of distances: $200 \mathrm{~m}, 400 \mathrm{~m}, 800 \mathrm{~m}, 1.2 \mathrm{~km}$, and $3.6 \mathrm{~km}$. For the Buffalo and Current River basins, sinuosity values ranged from approximately 1 to 3 ; a value of 1.5 may be considered a threshold between meandering streams and those that are relatively straight, whereas values greater than 2 may be considered very sinuous (Leopold and others, 1957).

\section{Statistical Classification}

Channel metrics were used to inform geomorphic classification along the length of the Jacks Fork, Current, and Buffalo Rivers using multivariate statistics. Statistical analyses were performed using the Python programming language (version 3.7.3) and Scipy packages (version 1.2.1).

We performed exploratory statistical analyses based on the GIS-derived metrics available in each park. For each of the three rivers, the metrics included in the first iteration of analysis were channel width, standard deviation of channel width, valley width, confinement, distance to valley wall, braid index, sinuosity (800-m measurement interval), gravel-bar area, and bluff area. We performed a principal component analysis (PCA) to determine a subset of variables to use in the subsequent clustering analysis. A PCA is an unsupervised statistical technique that may be used for reducing dimensions in multivariate data. Before clustering, data were rescaled by dividing values by the standard deviation across all observations for each variable.

Each river was classified using agglomerative hierarchical clustering, performed with the minimum variance method (Ward, 1963). The approach iteratively merges clusters by minimizing dissimilarity. The hierarchical clustering algorithm results in a dendrogram, which can be used to aid identification of natural breaks in number of clusters. Several methods exist for evaluating the optimum number of clusters, each with different assumptions and limitations, and requiring some degree of subjectivity in determining the final number of clusters. Results for different numbers of clusters (ranging from 2 to 5) for each of the rivers are presented in the "Longitudinal Channel Classification" section, with the select number of clusters determined from naturally occurring breaks (also known as trimming distances) that emerged in the clustering analysis.

\section{Gravel-Bar Inventory}

To assess the movement of gravel through the drainage network in the Current and Buffalo River basins, an inventory of gravel-bar area was developed for each park based on mapping from repeat low-altitude aerial photography. Jacobson and Gran (1999) conducted a similar analysis on the Current River, but they were limited to imagery from 2 years (1992 and 1996). The reanalysis presented in this report expanded the temporal and spatial scope of the initial gravel-bar inventory to include additional photograph series and to extend the analysis to the Buffalo River and Jacks Fork. 
To determine the photograph series for use in the analysis, we inventoried imagery available for each park. Some imagery was available in digital format online (such as USDA NAIP); in other cases, physical copies of imagery were retrieved from local NPS archives at BUFF and OZAR. After reviewing available imagery, photograph series were selected for use in the gravel-bar inventory based on image quality, extent (full or partial coverage of the entire park), and timing (maintaining at least 3 years between each set of images analyzed). For OZAR, years selected for analysis were 1992, 1996, 2005, 2010, and 2014 (fig. 6); imagery from 1992 was available for the Current River only. For BUFF we selected 1982, 2000, 2006, 2010, and 2013 for analysis (fig. 7). The series of photographs used for the gravel-bar inventory are listed in table 2.

Georeferenced aerial imagery was acquired from the USGS Earth Explorer (U.S. Geological Survey, n.d.) and the USDA Geospatial Data Gateway (U.S. Department of Agriculture, n.d.). Hardcopy imagery that had not been previously georeferenced was scanned and georeferenced to modern photographs (2009 NAIP imagery) using easily identifiable common features, referred to as ground control points (GCPs; Hughes and others, 2006). The GCPs were only placed in the valley bottoms, or as near as possible, to reduce the influence of terrain-induced image distortion; thus, the upland areas were not georeferenced. Efforts were made to evenly distribute GCPs so that they encompassed as much of the stream in each image as possible. The GCPs were preferentially located in the following order: buildings, road intersections, road/stream crossings, rocks/boulders, trees, edges of actively plowed fields, and other features identifiable in both sets of photographs. A residual value of $5 \mathrm{~m}$ was used as a threshold above which a GCP was deemed not useable. Upon reaching a satisfactory warp, the photograph was transformed using a second-order polynomial.

After identifying suitable photograph series and georeferencing as needed, we evaluated the longitudinal distribution of gravel along the Jacks Fork, Current, and Buffalo Rivers. Gravel deposits were mapped using either an automated image-processing classification or visual identification. The automated classification was implemented using the Image Classification Toolbox in ArcGIS. Because the spectral qualities of gravel are distinct from water and vegetation, the supervised classification was generally successful. For images that were not able to be classified based on spectral characteristics, gravel deposits were digitized by hand. The longitudinal distribution of gravel was inventoried along address points at 200-m intervals, using the address points established as part of the channel classification component of the project described above. Gravel-bar area was quantified within a circular 125-m search radius around each point. Bar area at each point was then normalized by the total gravel-bar area in a given year to control for differences in discharge among years (Jacobson and Gran, 1999).

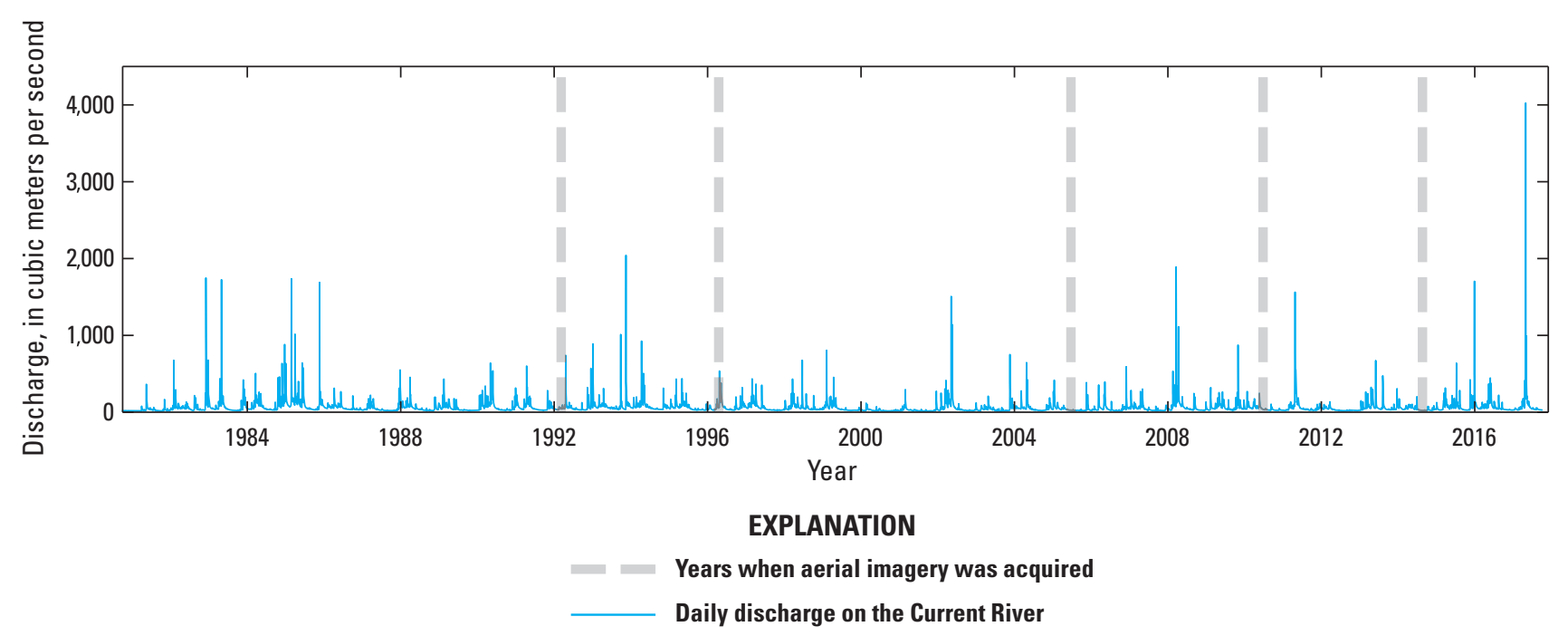

Figure 6. Daily discharge on the Current River as measured at U.S. Geological Survey streamgage 07067000 (Current River at Van Buren, Missouri). Dashed vertical lines show when aerial images used in bar inventory were acquired. 


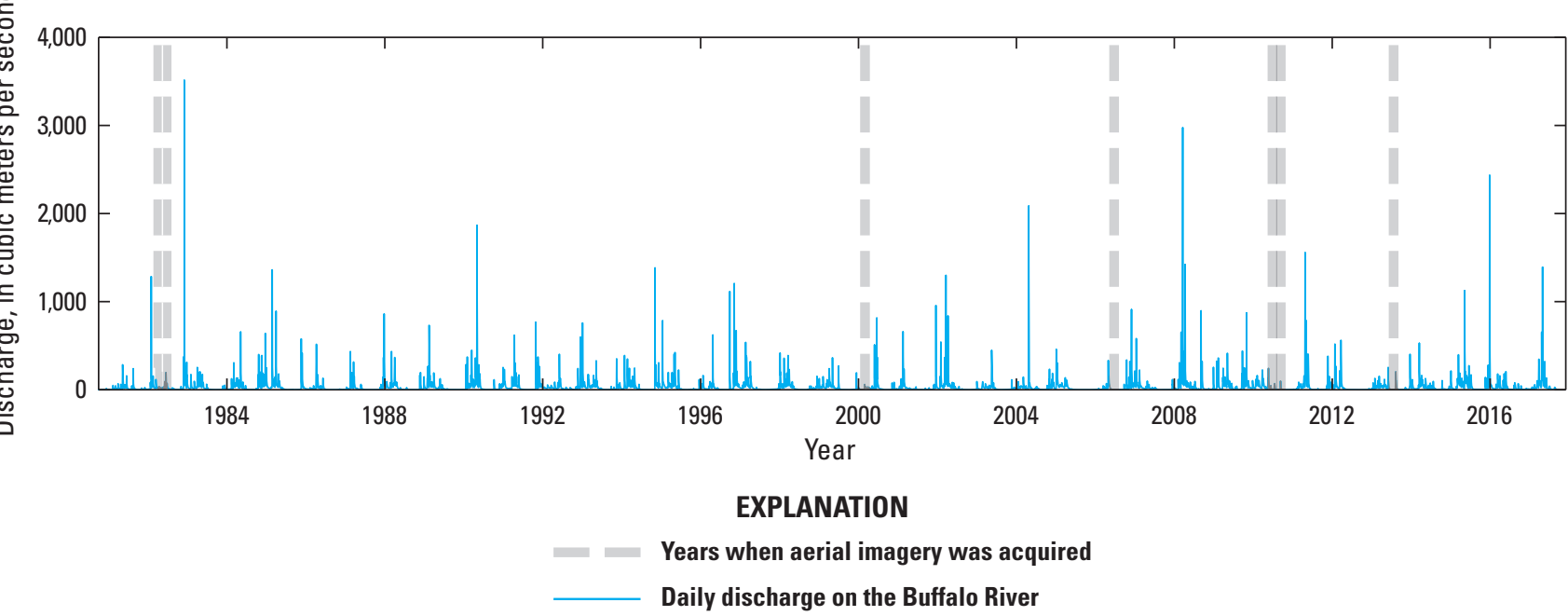

Figure 7. Daily discharge on the Buffalo River as measured at U.S. Geological Survey streamgage 07056000 (Buffalo River near St. Joe, Arkansas). Dashed vertical lines show when aerial images used in the bar inventory were acquired.

Table 2. Aerial imagery used in gravel-bar inventory.

[m³/s, cubic meter per second; OZAR, Ozark National Scenic Riverways; NAIP, National Aerial Inventory Program; auto, automatic classification method; BUFF, Buffalo National River; DOQ, Digital Orthophoto Quadrangle; USGS, U.S. Geological Survey]

\begin{tabular}{|c|c|c|c|c|c|}
\hline River system & Year & Date $^{1}$ & Source & $\begin{array}{c}\text { Discharge range } \\
\qquad\left(\mathrm{m}^{3} / \mathrm{s}\right)\end{array}$ & $\begin{array}{c}\text { Classification } \\
\text { method }\end{array}$ \\
\hline Current River & 1992 & March 8 & $\mathrm{OZAR}^{2}$ & 51.8 & Jacobson $^{5}$ \\
\hline Current River/Jacks Fork & 1996 & April 16 & $\mathrm{OZAR}^{2}$ & 65.7 & Jacobson $^{5}$ \\
\hline Current River/Jacks Fork & 2005 & June $20-23$ & NAIP & $24.4-25.0$ & auto \\
\hline Current River/Jacks Fork & 2010 & June 30-July 1 & NAIP & $32.8-33.7$ & manual \\
\hline Current River/Jacks Fork & 2014 & July 22-August 25 & NAIP & $22.4-27.8$ & auto \\
\hline Buffalo River & 1982 & March 4-April 22 & $\mathrm{BUFF}^{2}$ & $16.4-24.5$ & manual \\
\hline Buffalo River & 2000 & April 5, 2000-January 28, 2002 & $\mathrm{DOQ}^{3}$ & $13.5-109.6$ & auto \\
\hline Buffalo River & 2006 & June 15-July 2 & NAIP & $1.3-2.0$ & auto \\
\hline Buffalo River & 2010 & June 27-August 12 & NAIP & $2.0-4.0$ & manual \\
\hline Buffalo River & 2013 & July 13-August 31 & NAIP & $1.7-12.4$ & auto \\
\hline
\end{tabular}

1Imagery for a given year often flown/collected on multiple dates; details are available as a USGS data release (Erwin, 2020).

2Physical imagery retrieved directly from parks indicated by OZAR and BUFF.

3Digital imagery retrieved from State of Arkansas Spatial Data Infrastructure, previously "GeoStor."

${ }^{4}$ Discharge for Buffalo River is from USGS streamgage 07056000 Buffalo River near St. Joe, Arkansas; Current River is from USGS streamgage 07067000 Current River at Van Buren, Missouri.

${ }^{5}$ Classification relies on the original analysis by Jacobson and Gran (1999). 


\section{Longitudinal Channel Classification}

Each of the three rivers were evaluated independently. Exploratory statistical analyses were performed using nine geomorphic variables: channel width, standard deviation in channel width, valley width, distance to valley wall, confinement, bar area, bluff area, braid index, and sinuosity (measured more than $800 \mathrm{~m}$ ). As described in the following sections, a subset of variables was identified for use in a clustering analysis for each river system.

\section{Ozark National Scenic Riverways Classification}

Longitudinal plots for the Current River illustrate spatial patterns in geomorphic attributes (fig. 8). As expected, width of the active channel increases in the downstream direction and is accompanied by an increase in valley width. Valley width increases notably downstream from the largest tributary, the Jacks Fork. Downstream from the Jacks Fork, where the valley is wider, there is a general increase in distance to valley wall and greater variability in both the area of gravel bars and bluffs. The correlation among the nine variables is shown in the scatter plot matrix (fig. 9).

The principal component analysis of standardized geomorphic variables for the Current River further illustrates the interrelations among variables (figs. 10, 11). Valley width and distance to valley wall are interrelated and positively loaded on each of the three factors. Similarly, channel width and the standard deviation of channel width are closely related. Both bar area and bluff area are positively loaded on component 1 and negatively loaded on component 2 .

An objective of the present study was to evaluate geomorphic attributes related to stable and disturbance reaches, as defined by Jacobson (1995). Based on the outcome of the PCA analyses, we selected valley width, channel width, and bar area to perform the clustering analysis. These three variables were relatively independent for the Current River and captured elements of qualitative descriptions of stable and disturbance reaches. Valley width relates to differences in bedrock lithology, and interaction with valley wall was identified as a possible causal factor for the spatial distribution of stable and disturbance reaches. Channel width relates to the braid index, as greater channel width is correlated with multiple threads. Bar area was selected because it indicates storage of sediment in the active channel and potential depositional zones, and may be indicative of reaches identified in qualitative visual assessments of channel planform as disturbance reaches or sedimentation zones.

As described in the "Statistical Classification" section, hierarchical clustering techniques were used to identify naturally occurring classes, as illustrated by the dissimilarity space, or distances, in the dendrogram (fig. 12). For the Current River, we considered results indicating natural breaks in the dendrogram occurring at two, three, and five clusters. With two clusters, the first cluster is characterized by relatively narrow channel width, narrow valley width, and low bar area, whereas the second cluster has relatively high channel width, high valley width, and greater bar area (fig. 13). The classification with three clusters results in an additional cluster with high channel and valley widths, but relatively low bar area. The identification of five classes provides a more nuanced segregation of channel types in the Current River, showing a wider range in physical attributes downstream from the Jacks Fork where there was an abrupt increase in drainage area, and thus discharge (fig. 14).

The spatial organization of the different clusters is shown in maps of the Current River through the study area (fig. 15). A similarity among the analysis for the two, three, and five clusters is the pronounced break in channel morphology upstream and downstream from the Jacks Fork. Upstream from the Jacks Fork, the Current River has a relatively narrow valley. The narrow channel width provides relatively little accommodation space for storage of sediment within the active channel, resulting in smaller and less numerous gravel bars (fig. 8). Increasing the number of clusters results in an increase in the number of classes (degree of splitting) downstream from the Jacks Fork, but for all three groups of clusters, a single cluster is present upstream from the confluence (fig. 15).

On the Jacks Fork, approximately the upper $35 \mathrm{~km}$ of the channel has a relatively narrow valley, and a corresponding narrow channel width (fig. 16). This narrow valley corresponds to the section of river where the Jacks Fork is confined by the Roubidoux Formation, a dominantly sandstone formation (fig. 4). Farther downstream, through the Gasconade dolomite and Eminence and Potosi dolomites, valley width increases and there is a corresponding increase in variability in channel width and less interaction with the valley wall (fig. 16). Through the lower one-half of the Jacks Fork, the channel is less confined and there is a general increase in area of gravel bars.

As compared with the Current River, there is a higher degree of correlation between channel width and area of exposed gravel bar on the Jacks Fork (figs. 17-19). However, to facilitate comparison between the Jacks Fork and Current River, we used the same subset of variables used to perform the clustering analysis (channel width, valley width, and bar area). Distances in dissimilarity revealed natural breaks occurring at two, three, and four clusters (fig. 20).

As with the Current River, the two-cluster analysis for the Jacks Fork resulted in one cluster characterized by a relatively high channel width, high valley width, and greater bar area (fig. 21); the second of the two clusters has relatively narrow channel width, narrow valley width, and low bar area. Additionally, there is greater variability in reach attributes in the downstream section of the Jacks Fork (figs. 22, 23). In the case of the Jacks Fork, this corresponds to patterns in surficial geology. 

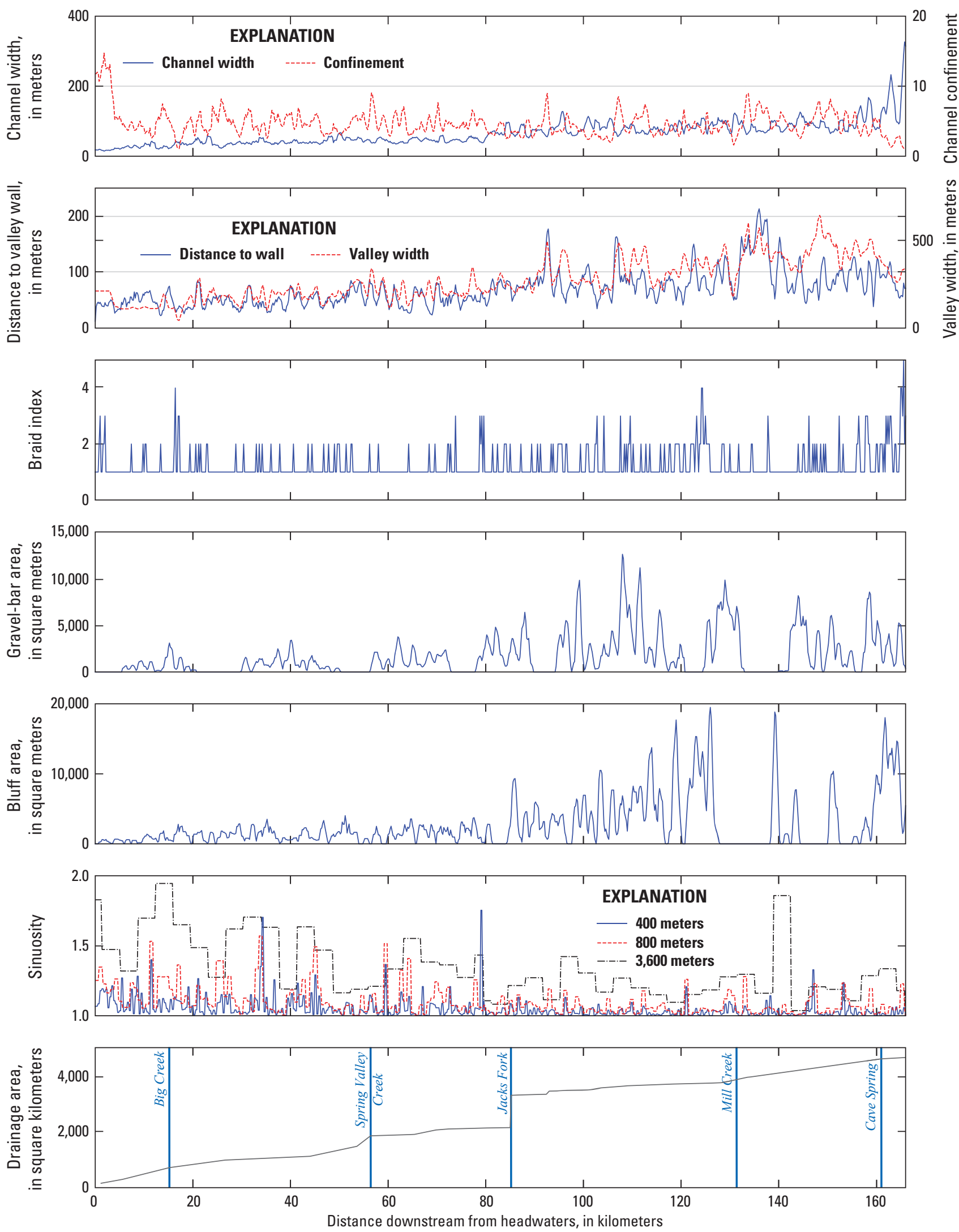

Figure 8. Longitudinal geomorphic characteristics for the Current River, 2010. 


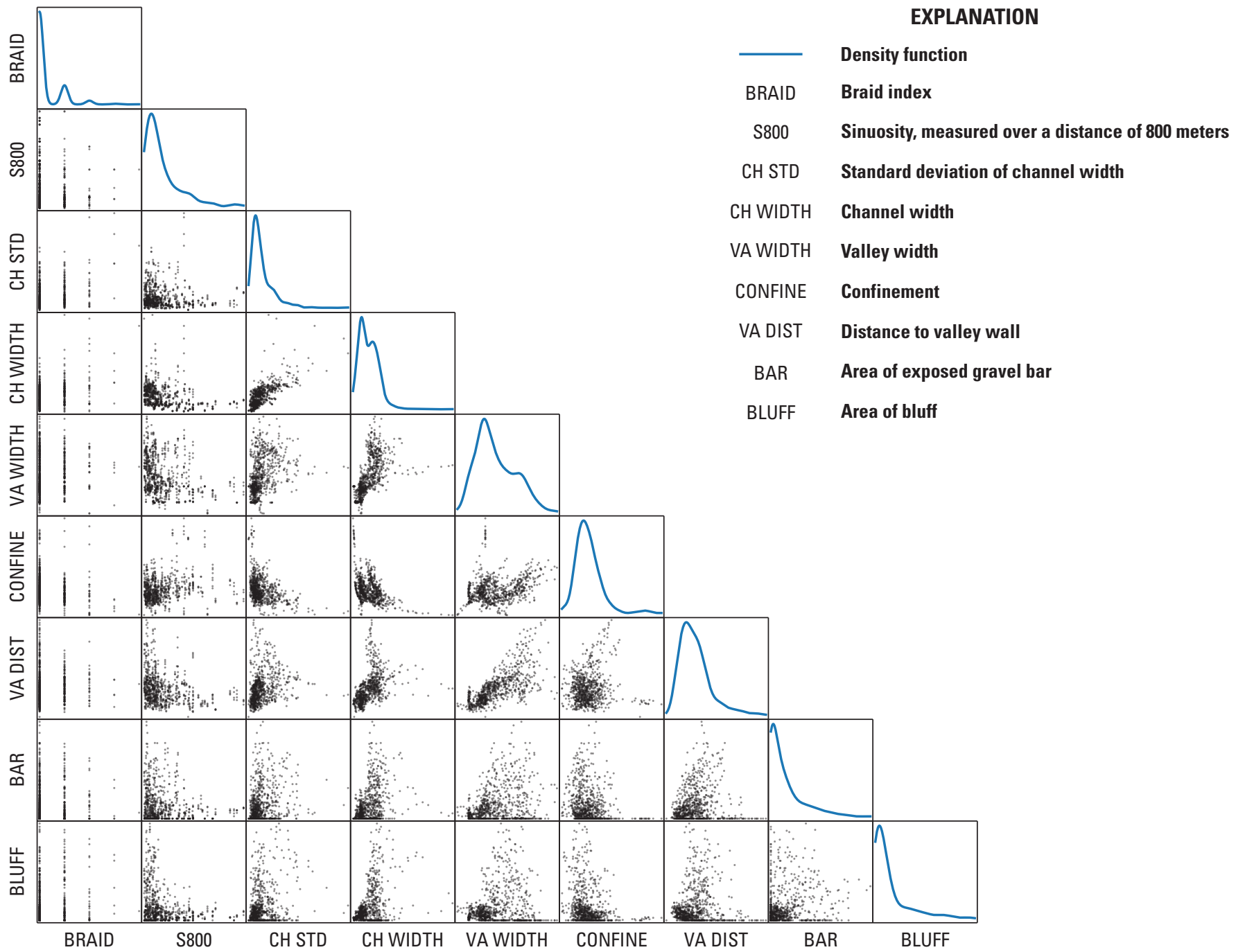

Figure 9. Bivariate scatter and frequency plots of nine geomorphic variables determined from analysis of imagery for the Current River, 2010. 


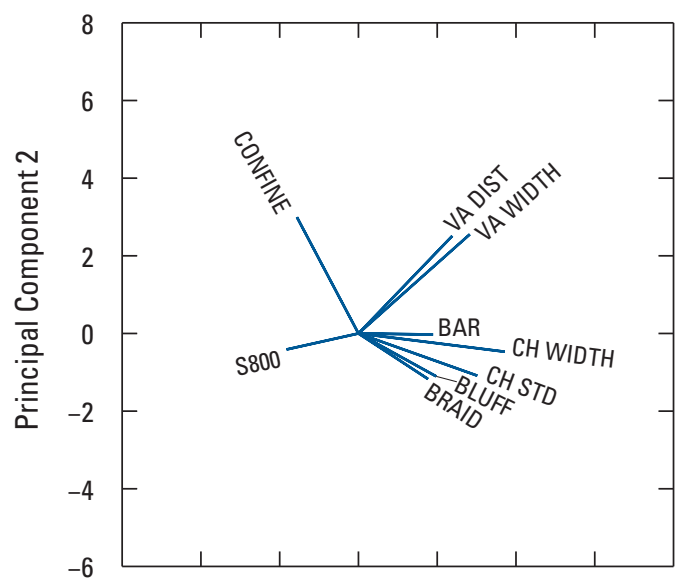

\section{EXPLANATION}

$\begin{array}{clcl}\text { BRAID } & \text { Braid index } & \text { VA WIDTH } & \text { Valley width } \\ \text { S800 } & \begin{array}{c}\text { Sinuosity, measured over } \\ \text { a distanceof } \mathbf{8 0 0} \text { meters }\end{array} & \text { CONFINE } & \text { Confinement } \\ \text { CH STD } & \begin{array}{c}\text { Standard deviation of } \\ \text { channel width }\end{array} & \text { VA DIST } & \text { Distance to valley wall } \\ & \quad \text { BAR } & \text { Area of exposed gravel bar }\end{array}$

CH WIDTH Channel width BLUFF Area of bluff
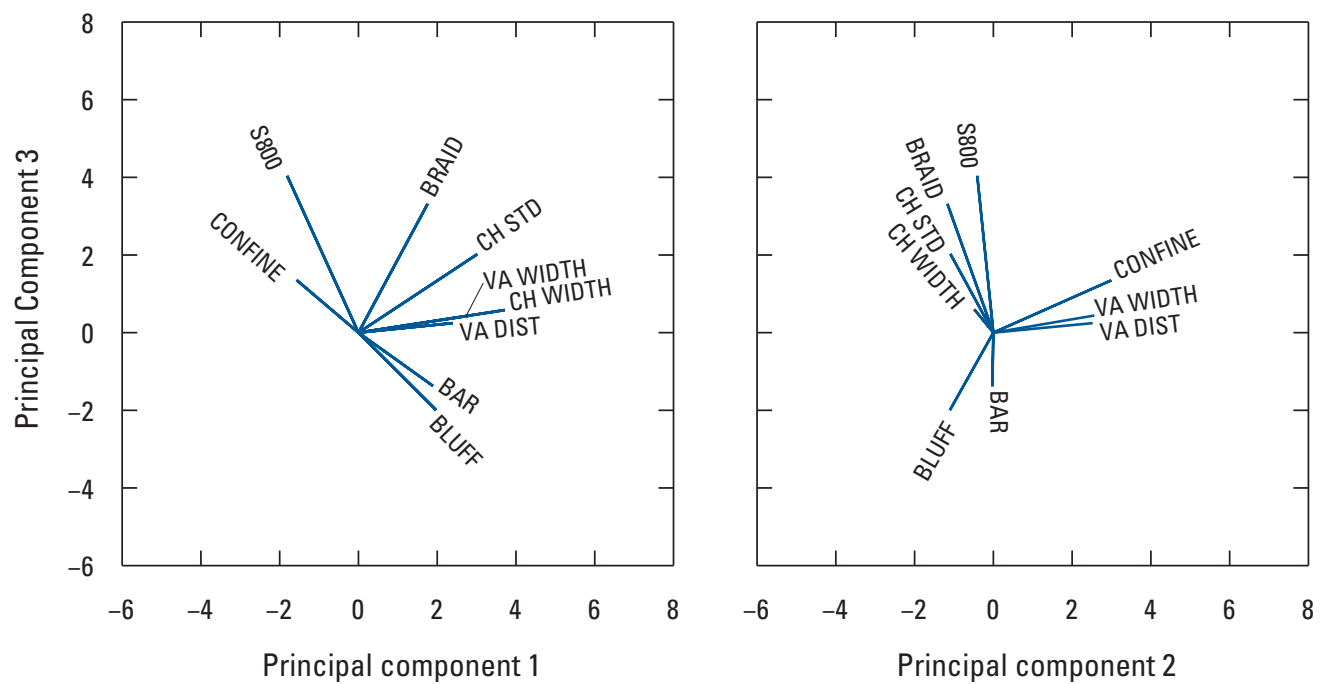

Figure 10. Principal component analysis of standardized geomorphic variables for the Current River. 


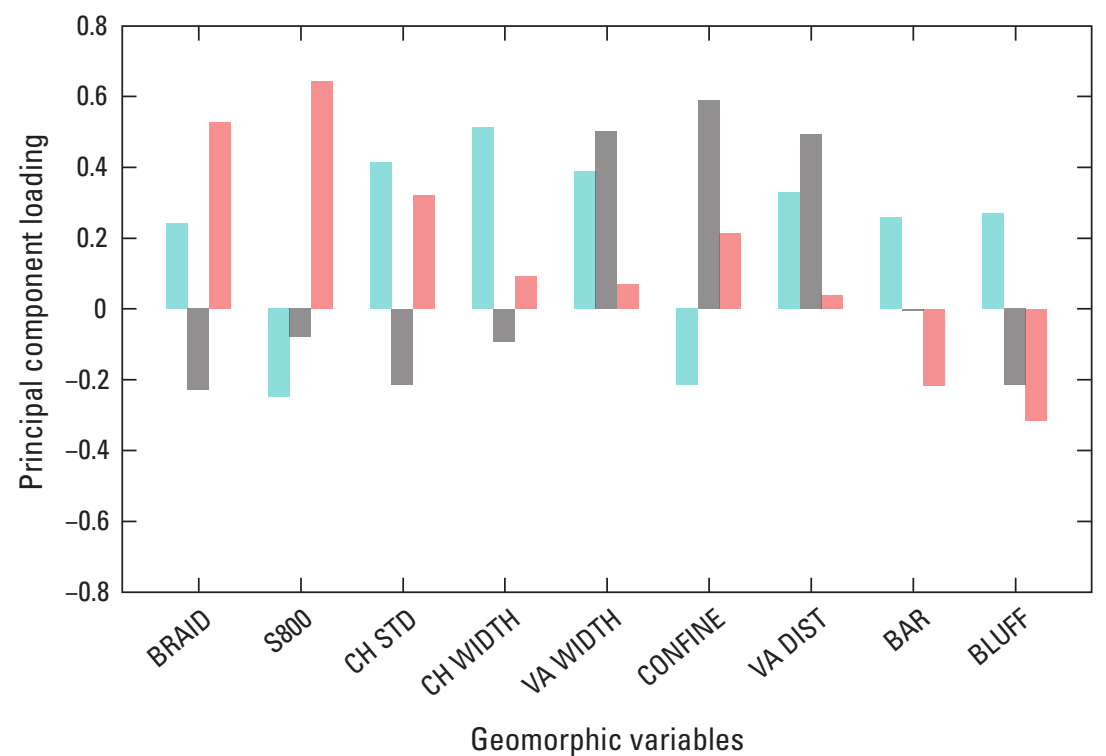

\begin{tabular}{|c|c|}
\hline \multicolumn{2}{|r|}{ EXPLANATION } \\
\hline 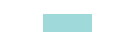 & Component 1 \\
\hline - & Component 2 \\
\hline 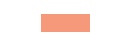 & Component 3 \\
\hline BRAID & Braid index \\
\hline S800 & $\begin{array}{l}\text { Sinuosity, measured over a distance } \\
\text { of } 800 \text { meters }\end{array}$ \\
\hline CH STD & Standard deviation of channel width \\
\hline CH WIDTH & Channel width \\
\hline VA WIDTH & Valley width \\
\hline CONFINE & Confinement \\
\hline VA DIST & Distance to valley wall \\
\hline BAR & Area of exposed gravel bar \\
\hline BLUFF & Area of bluff \\
\hline
\end{tabular}

Figure 11. Loading of geomorphic variables on each principal component for the Current River. [BRAID, Braid index; S800, sinuosity measured over a distance of 800 meters; CH STD, standard deviation of channel width; CH WIDTH, channel width; VA WIDTH, valley width; CONFINE, confinement; VA DIST, distance to valley wall; BAR, area of exposed gravel bar; BLUFF, area of bluff]

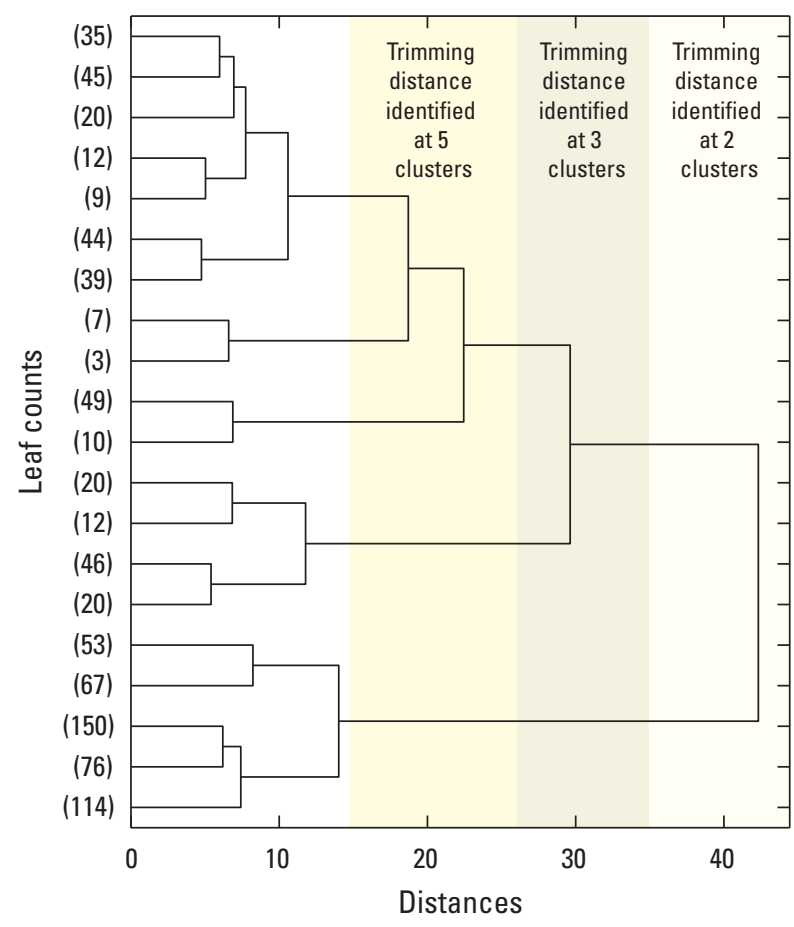

Figure 12. Dendrogram of Current River geomorphic characteristics, with trimming distances identified at two, three, and five clusters. 

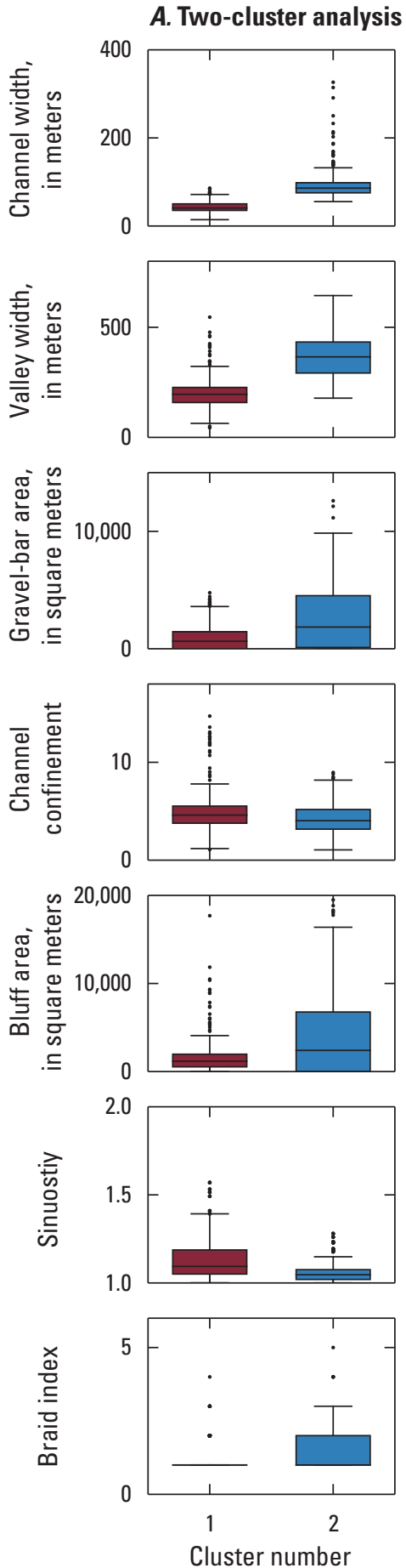

\section{B. Three-cluster analysis}
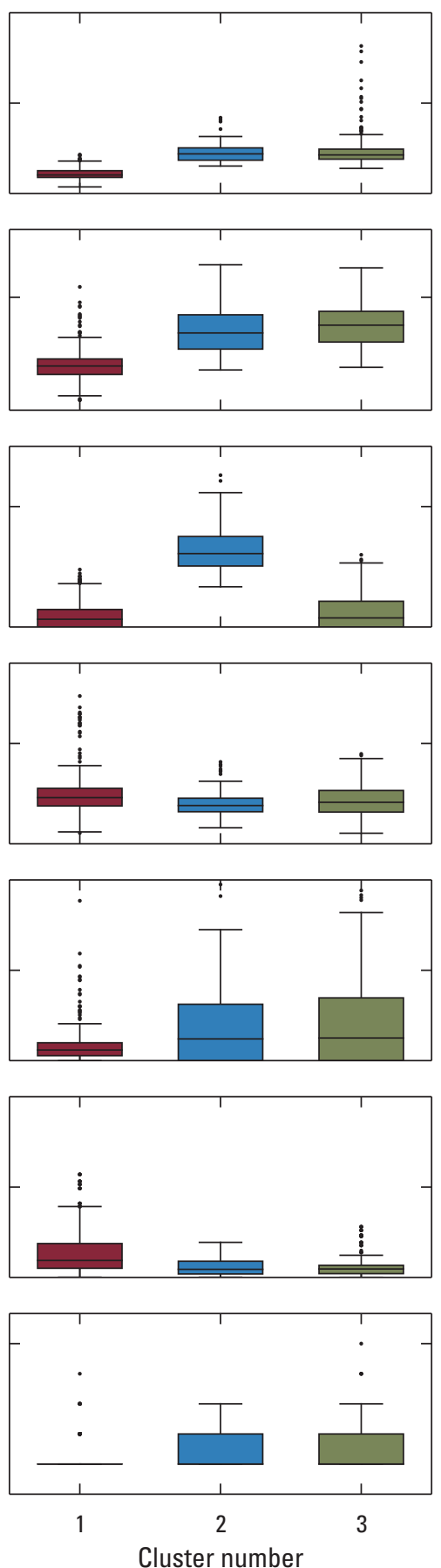

\section{EXPLANATION}

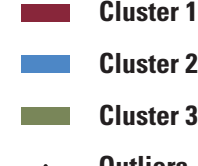

: Outliers

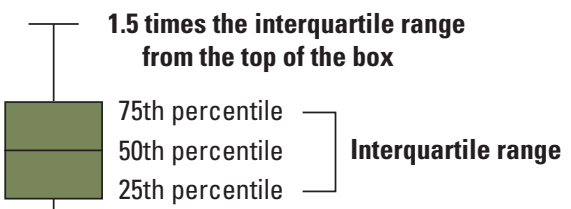

1.5 times the interquartile range from the bottom of the box

Figure 13. Results of Current River hierarchical clustering. $A$, Two-cluster analysis; and $B$, three-cluster analysis. Clusters were analyzed using three variables: channel width, valley width, and bar area. 

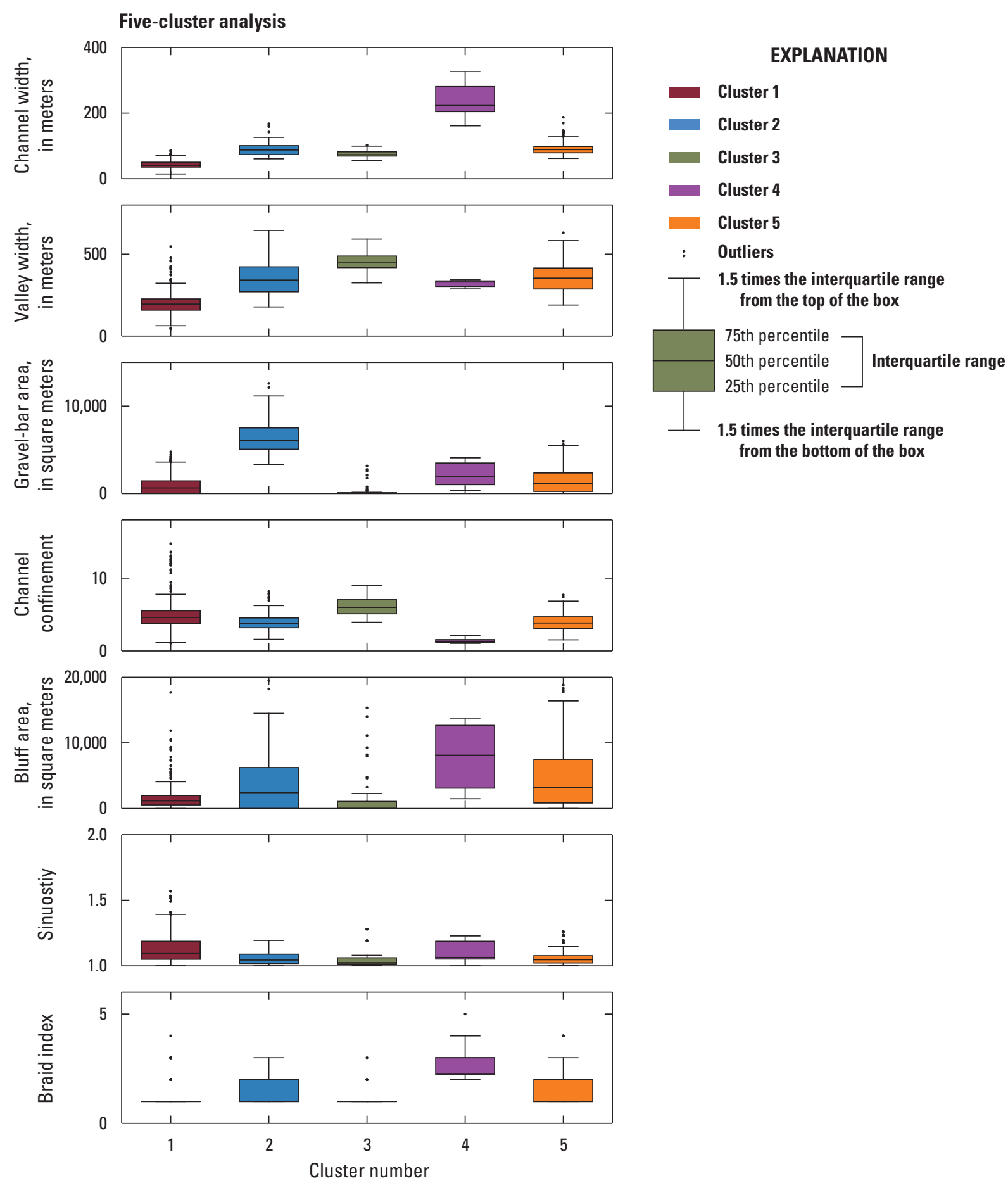

Figure 14. Results of Current River hierarchical clustering for five clusters. Clustering analysis was performed using three variables: channel width, valley width, and bar area. 
A. Two-cluster analysis

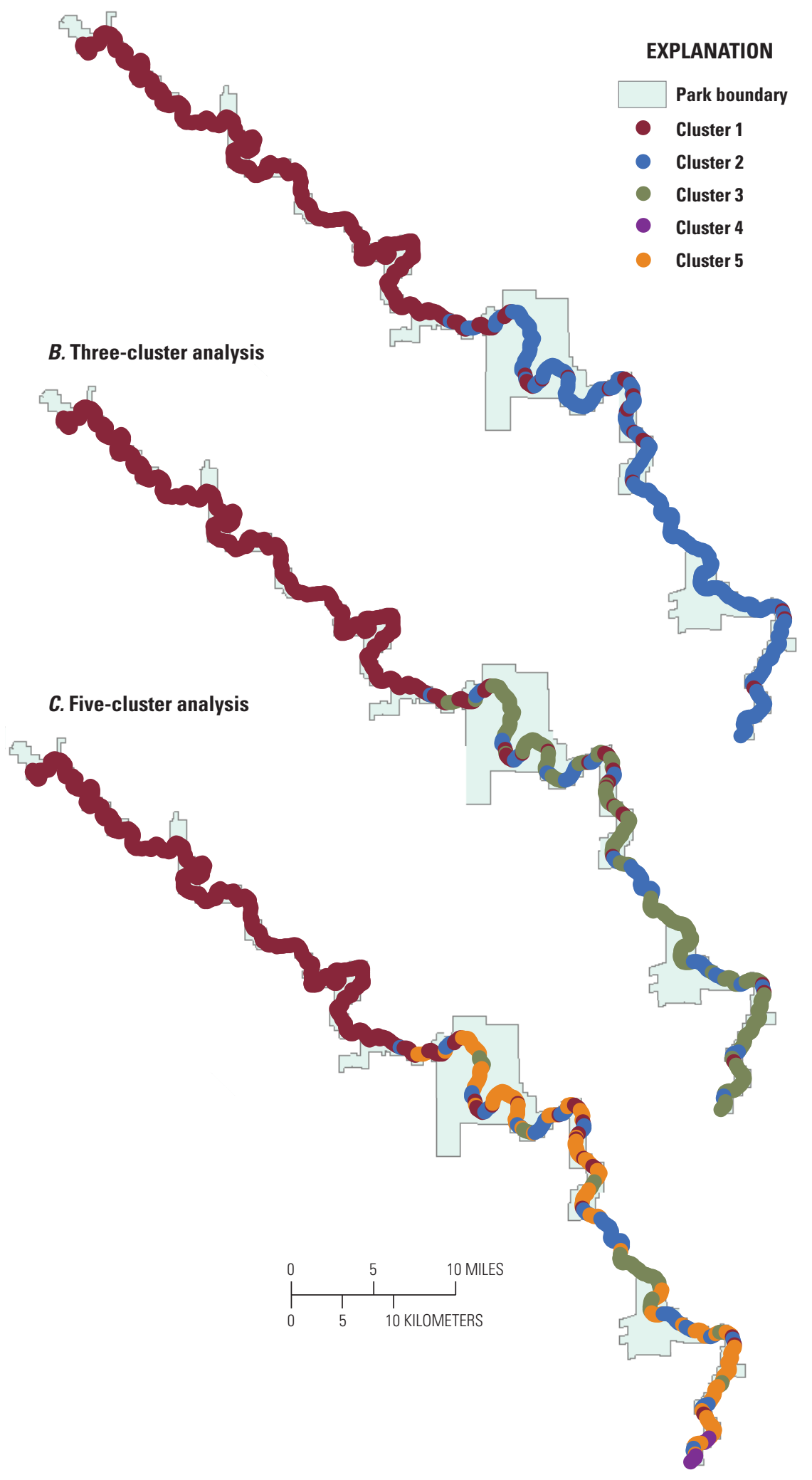

Figure 15. Hierarchical clustering results for the Current River. $A$, Two clusters; $B$, three clusters; and $C$, five clusters. 

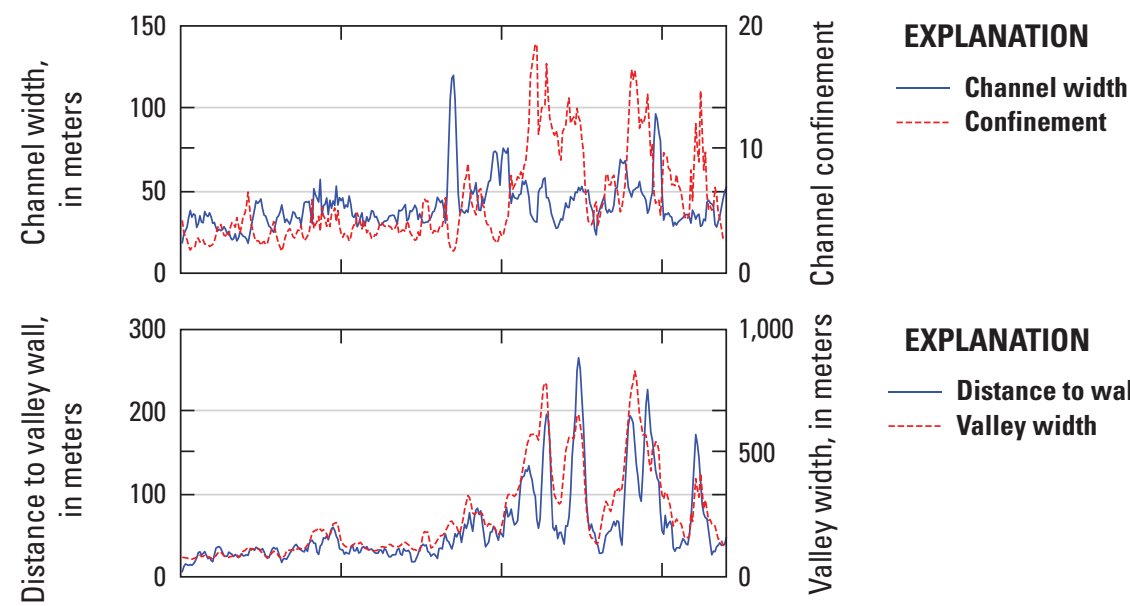

\section{EXPLANATION}
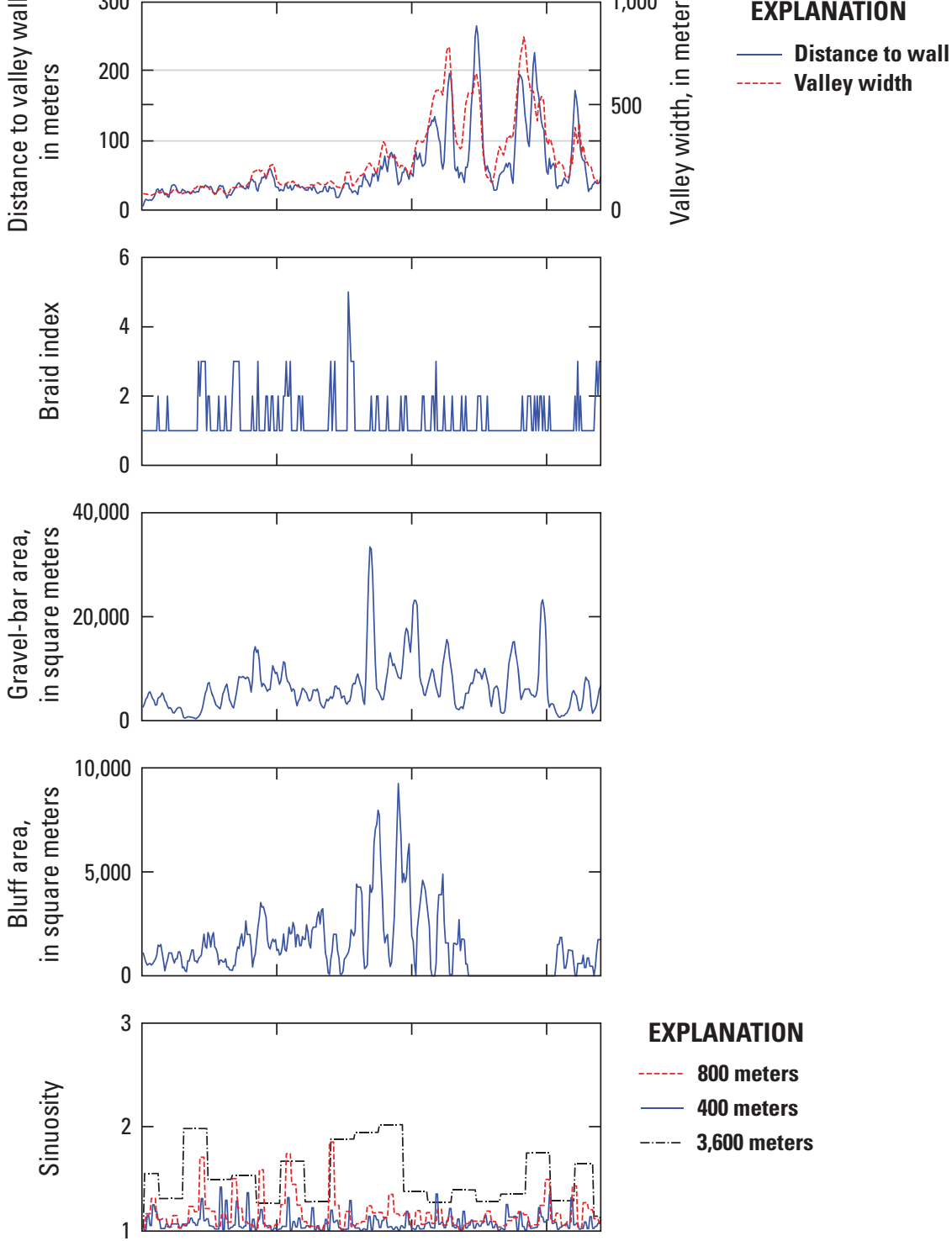

EXPLANATION

800 meters

- 400 meters

-..-- 3,600 meters

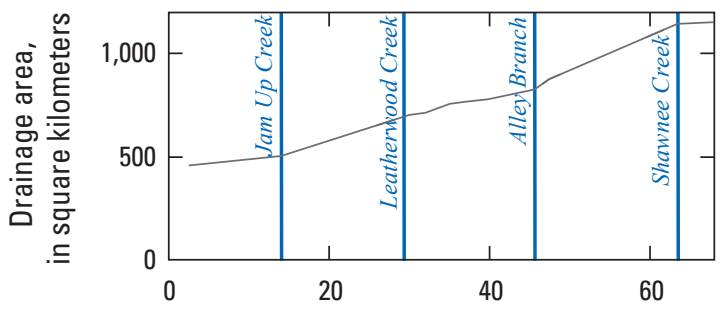

Distance downstream from headwaters, in kilometers

Figure 16. Longitudinal geomorphic characteristics for the Jacks Fork, 2010. 


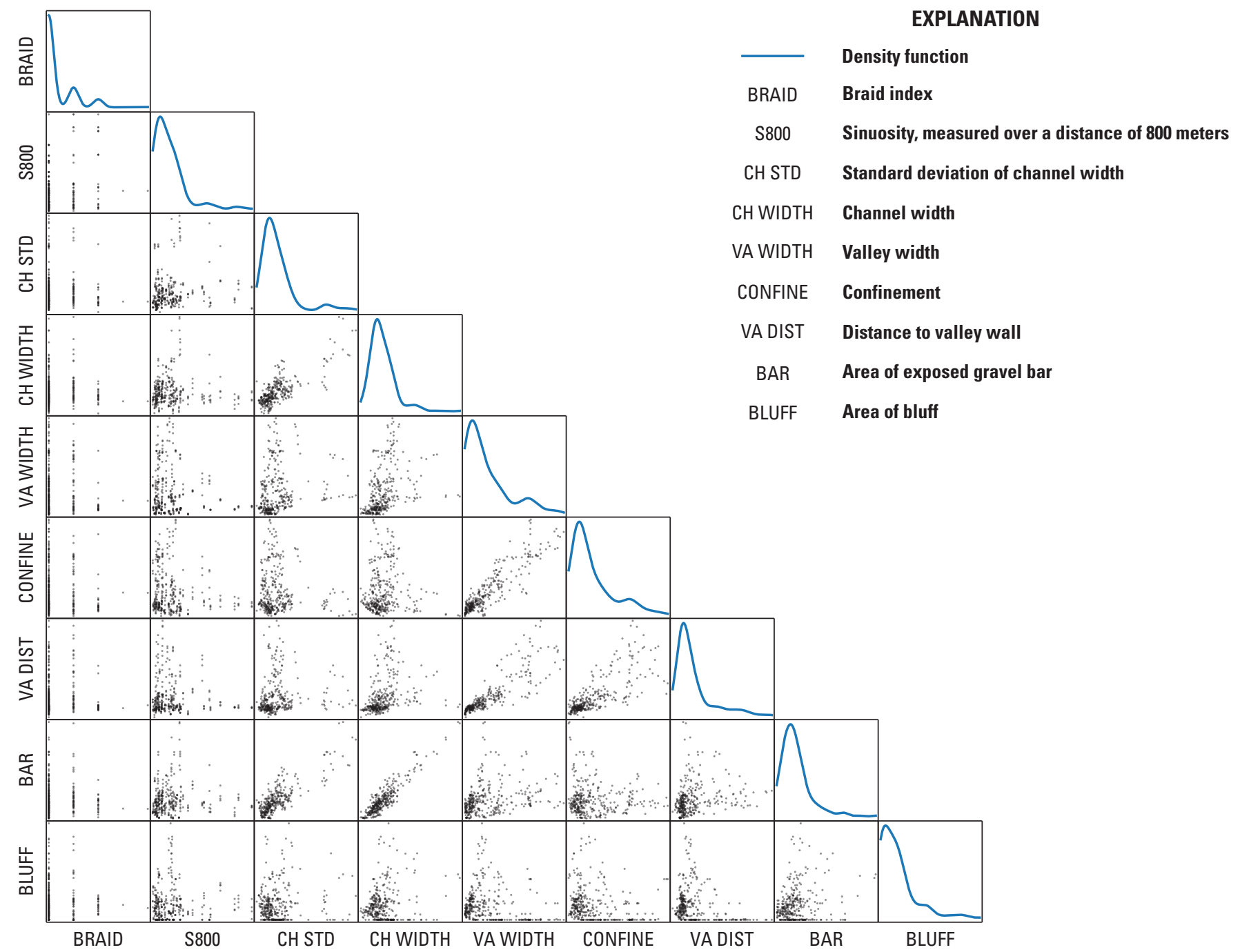

Figure 17. Bivariate scatter and frequency plots of nine geomorphic variables determined from analysis of imagery for the Jacks Fork, 2010. 


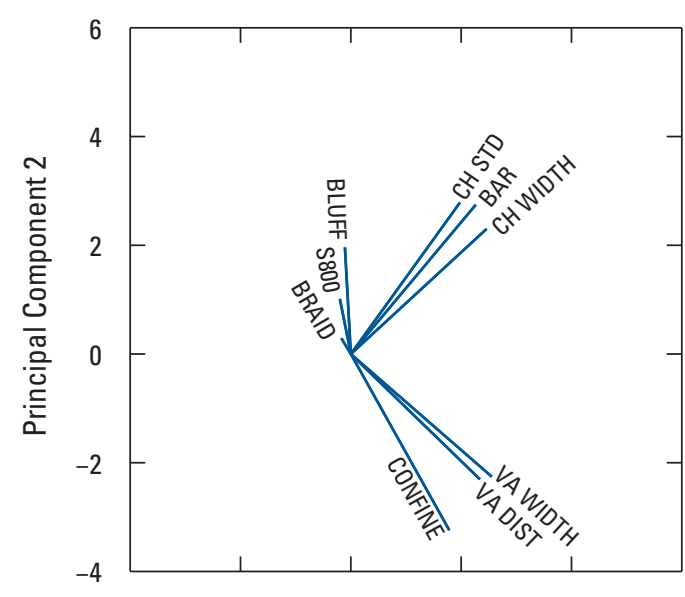

\begin{tabular}{clcl}
\multicolumn{3}{c}{ EXPLANATION } \\
BRAID & Braid index & VA WIDTH & Valley width \\
S800 & $\begin{array}{c}\text { Sinuosity, measured over } \\
\text { a distance of } 800 \text { meters }\end{array}$ & CONFINE & Confinement \\
CH STD & $\begin{array}{c}\text { Standard deviation of } \\
\text { channel width }\end{array}$ & VA DIST & Distance to valley wall \\
& BAR & Area of exposed gravel bar \\
CH WIDTH & Channel width & BLUFF & Area of bluff
\end{tabular}
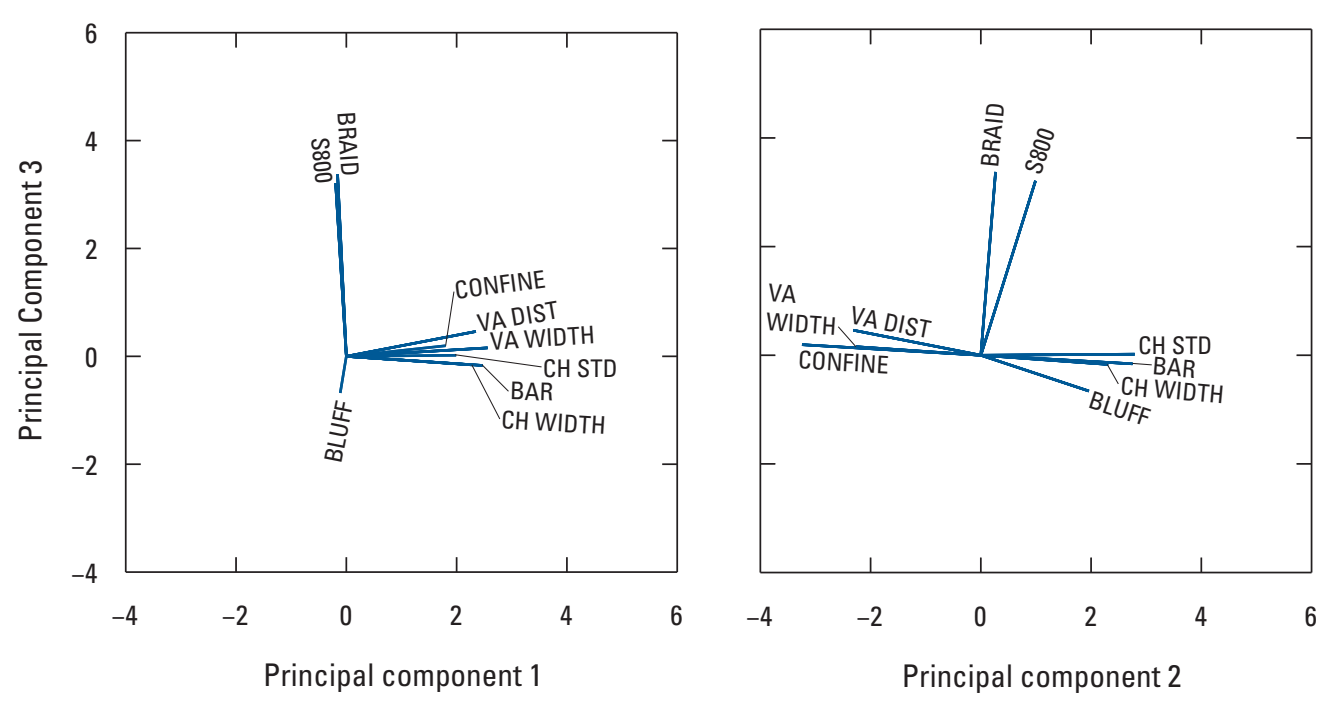

Figure 18. Principal component analysis of standardized geomorphic variables for the Jacks Fork. 


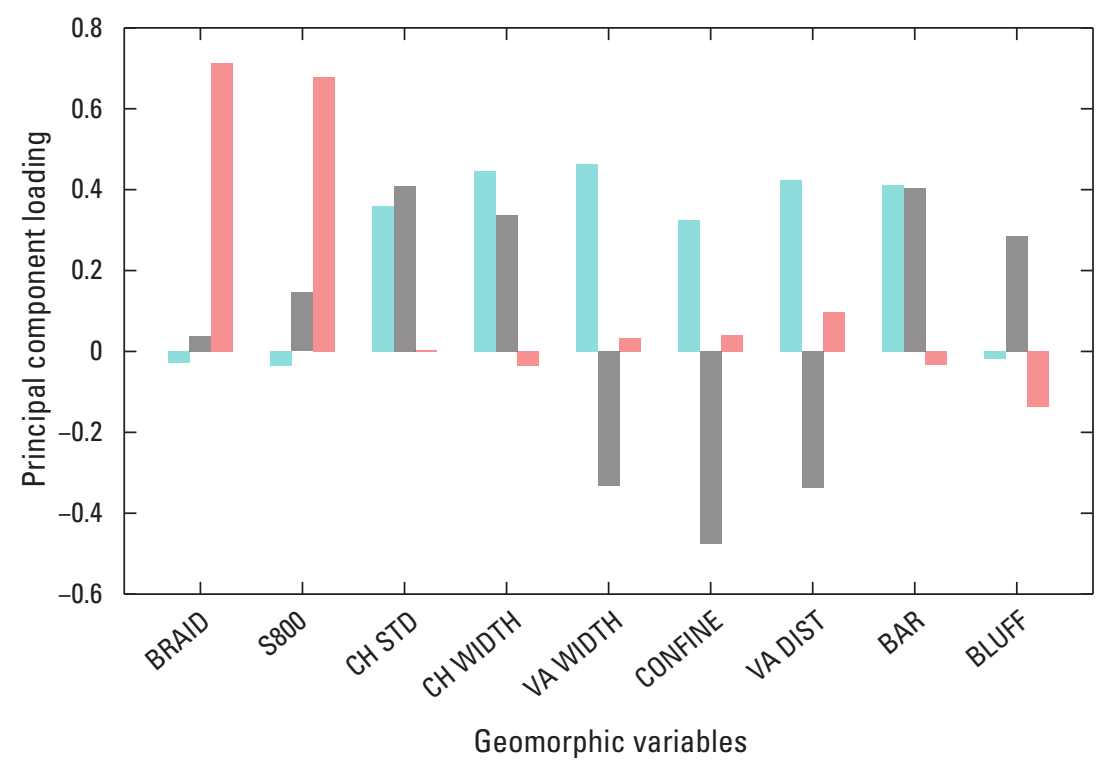

\begin{tabular}{|c|c|}
\hline & EXPLANATION \\
\hline$\square$ & Component 1 \\
\hline ש & Component 2 \\
\hline 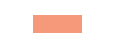 & Component 3 \\
\hline BRAID & Braid index \\
\hline S800 & $\begin{array}{l}\text { Sinuosity, measured over a distance } \\
\text { of } 800 \text { meters }\end{array}$ \\
\hline CH STD & Standard deviation of channel width \\
\hline CH WIDTH & Channel width \\
\hline VA WIDTH & Valley width \\
\hline CONFINE & Confinement \\
\hline VA DIST & Distance to valley wall \\
\hline BAR & Area of exposed gravel bar \\
\hline BLUFF & Area of bluff \\
\hline
\end{tabular}

Figure 19. Loading of geomorphic variables on each principal component for the Jacks Fork. [BRAID, Braid index; S800, sinuosity measured over a distance of 800 meters; CH STD, standard deviation of channel width; CH WIDTH, channel width; VA WIDTH, valley width; CONFINE, confinement; VA DIST, distance to valley wall; BAR, area of exposed gravel bar; BLUFF, area of bluff]

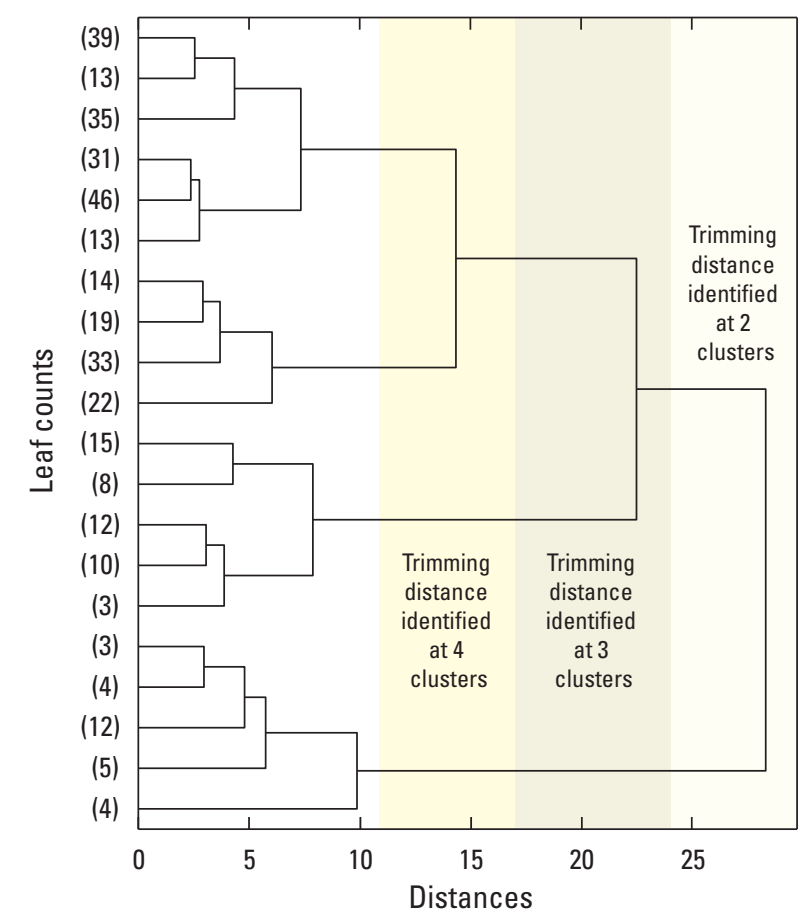

Figure 20. Dendrogram of Jacks Fork geomorphic characteristics, with trimming distances identified at two, three, and four clusters. 

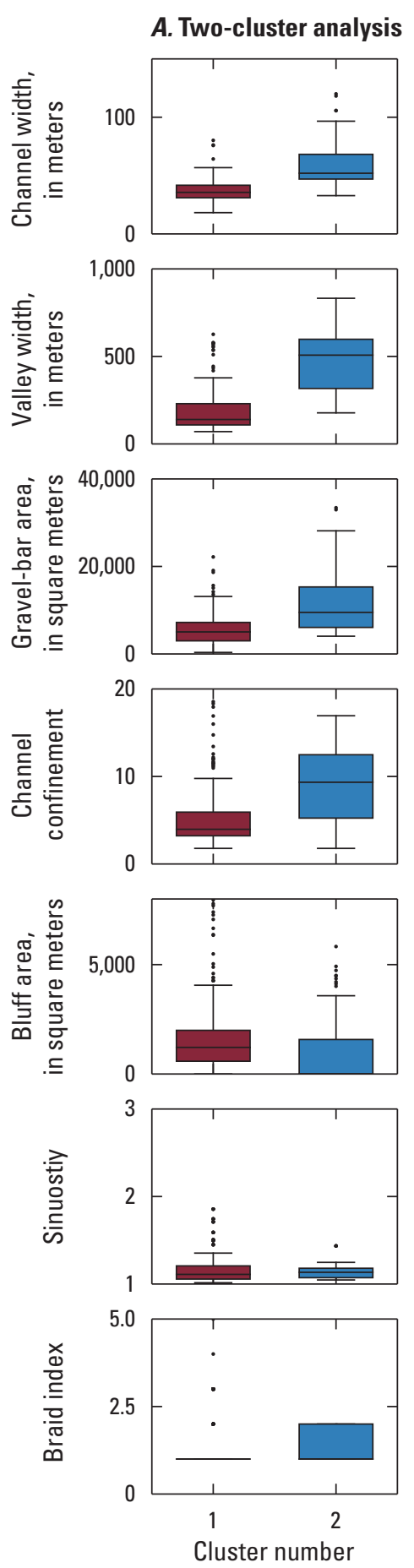

B. Three-cluster analysis
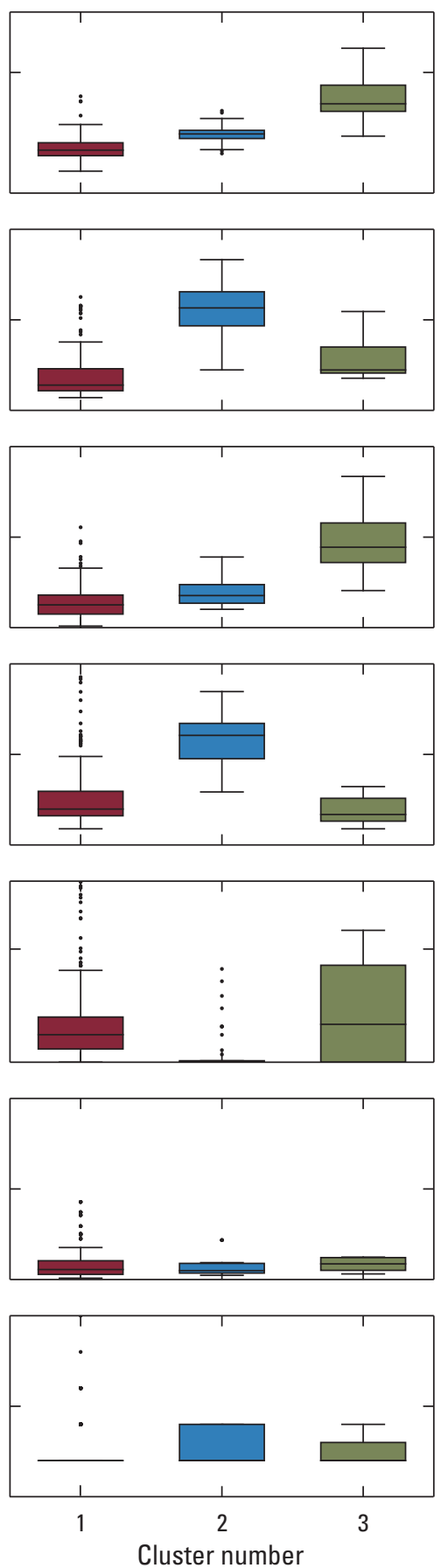

EXPLANATION

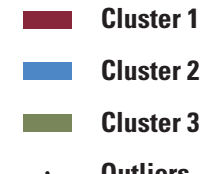

: Outliers

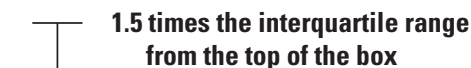
from the top of the box

75th percentile 50th percentile Interquartile range 25th percentile

1.5 times the interquartile range from the bottom of the box

Figure 21. Results of Jacks Fork hierarchical clustering. $A$, Two-cluster analysis; and $B$, three-cluster analysis. Clustering analysis was performed using three variables: channel width, valley width, and gravel-bar area. 


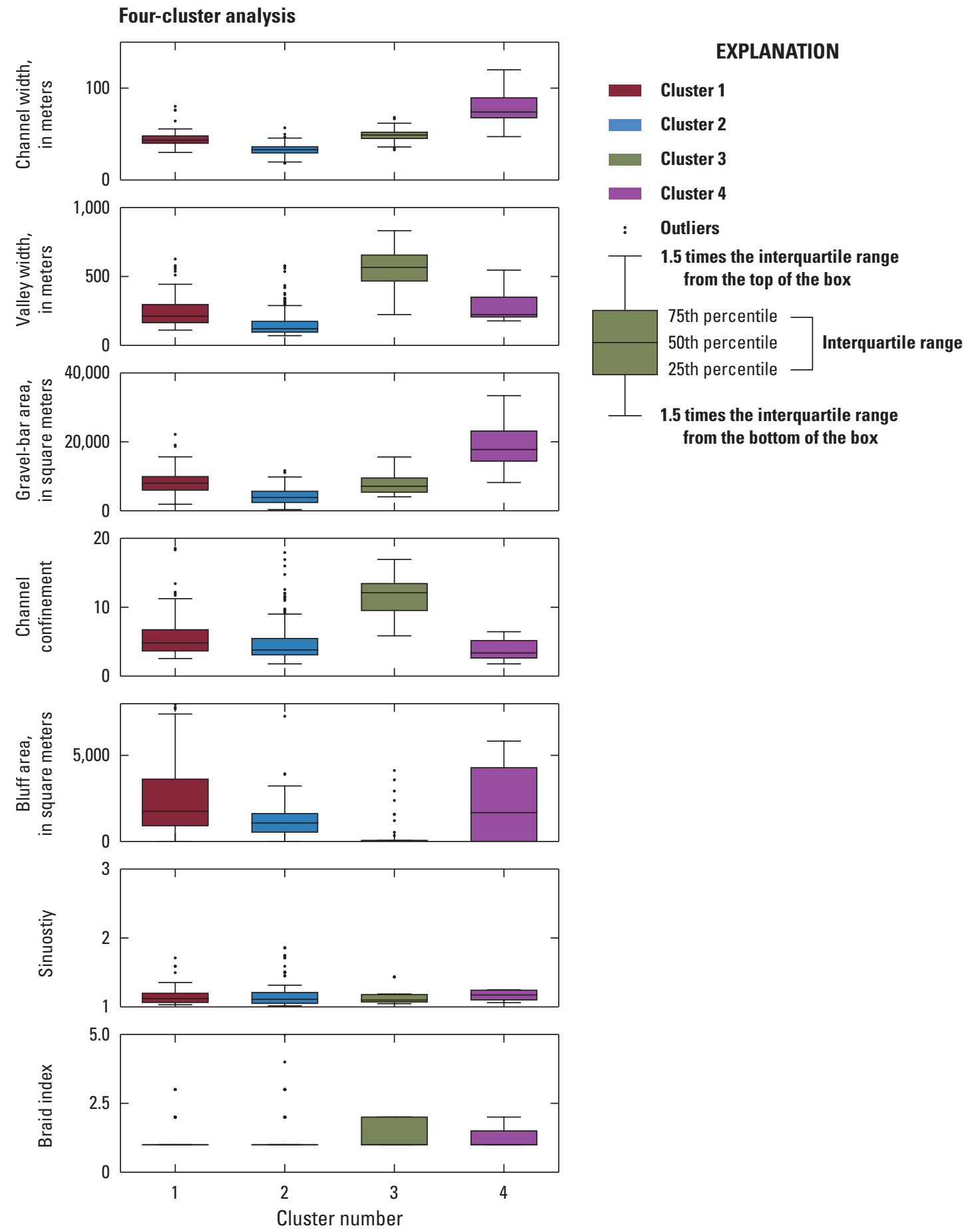

Figure 22. Results of Jacks Fork hierarchical clustering for four clusters. Clustering analysis was performed using three variables: channel width, valley width, and gravel-bar area. 

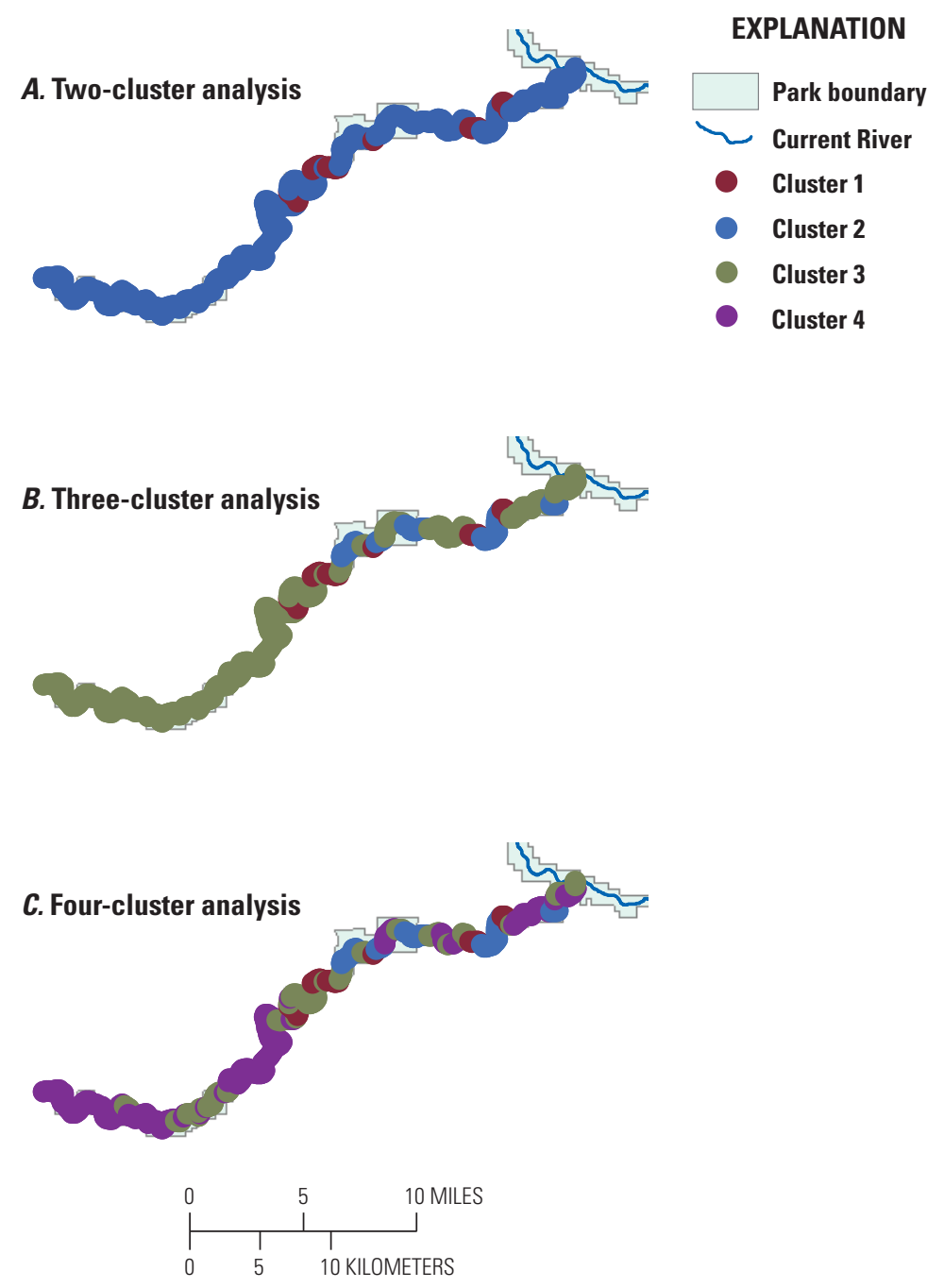

Figure 23. Hierarchical clustering results for Jacks Fork. $A$, Two clusters; $B$, three clusters; and $C$, four clusters.

\section{Buffalo National River Classification}

On the Buffalo River, distinct longitudinal patterns emerge that also indicate geologic control on fluvial geomorphology (fig. 24). Keen-Zebert and others (2017) identified four lithologic reaches, where the channel alternates between the Boone Formation and Everton Formation. Although the two formations have similar mechanical resistance, the cherty limestone of the Boone Formation is less resistant to chemical weathering than the sandy dolomite and sandstone of the Everton Formation (Thaler and Covington, 2016; Keen-Zebert and others, 2017). Thus, the valley width is relatively wide through the Boone Formation (in the headwaters and again approximately $100 \mathrm{~km}$ downstream from the headwaters owing to faulting) and narrower where it has incised into the Everton Formation (fig. 5). In narrower sections, there is greater interaction with the valley wall, and there is a general increase in gravel-bar area in the downstream direction (fig. 24).
Correlation among variables is illustrated in the scatter plot matrix (fig. 25). There is a greater correlation between channel width and bar area on the Buffalo River than on the Current River, and channel width and bar area were positively loaded on component 1 of the PCA (figs. 26 and 27). Valley width, the third variable selected for the clustering analysis, was positively loaded on all three components (though just weakly on components 1 and 3).

Clustering was performed using the same three variables as Current River and Jacks Fork: channel width, valley width, and bar area. Naturally occurring breaks, or trimming distances, were identified at two, three, and five clusters (fig. 28). As with the rivers in OZAR, clustering performed for the Buffalo River resulted in classes with distinct channel and valley width attributes, whereas bluff area, sinuosity, and braid index were relatively similar among clusters (figs. 29, 30). In BUFF, however, we observed greater longitudinal variation in the distribution of clusters as compared with the Current River and Jacks Fork (fig. 31). 

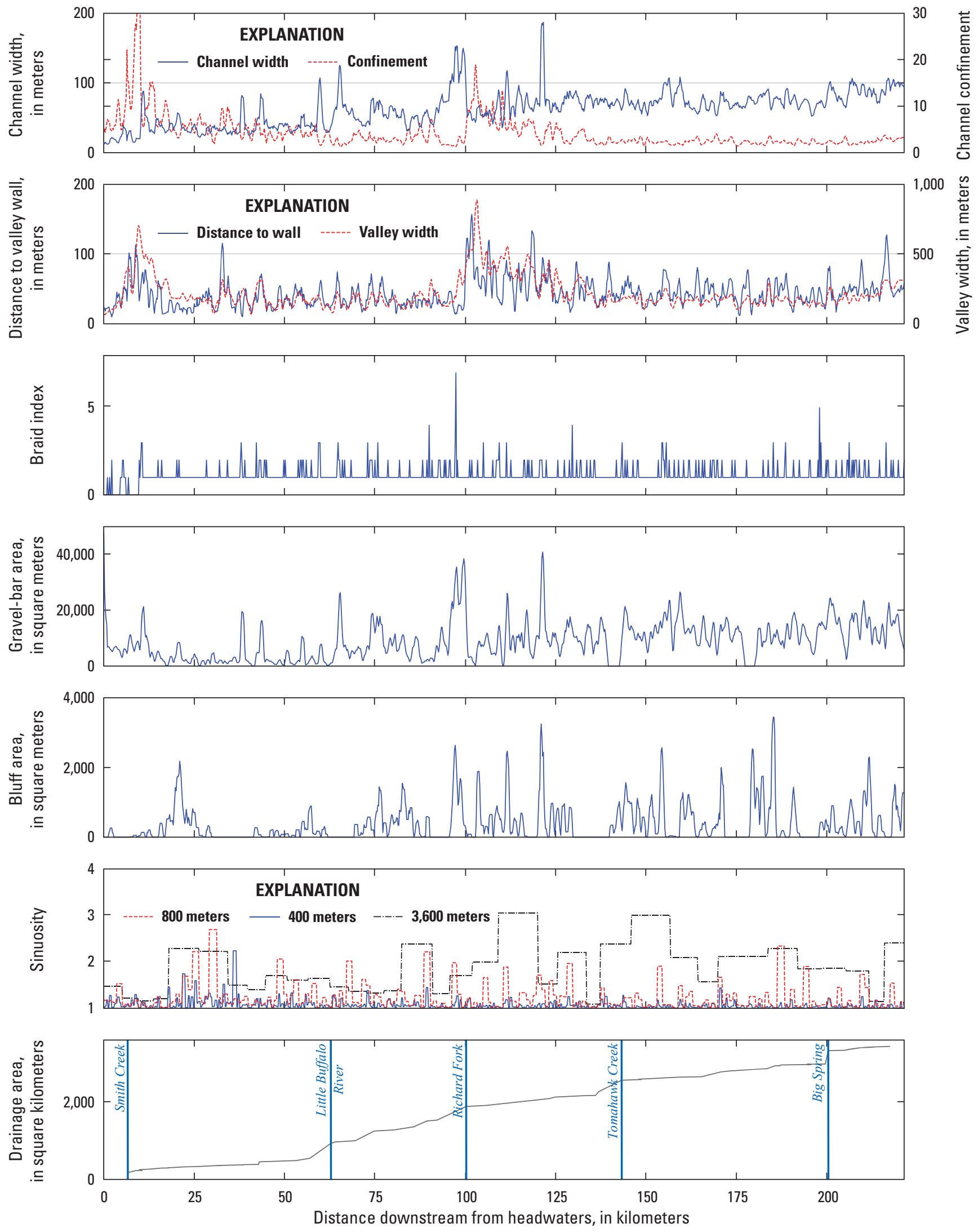

Figure 24. Longitudinal geomorphic characteristics for the Buffalo River, 2010. 


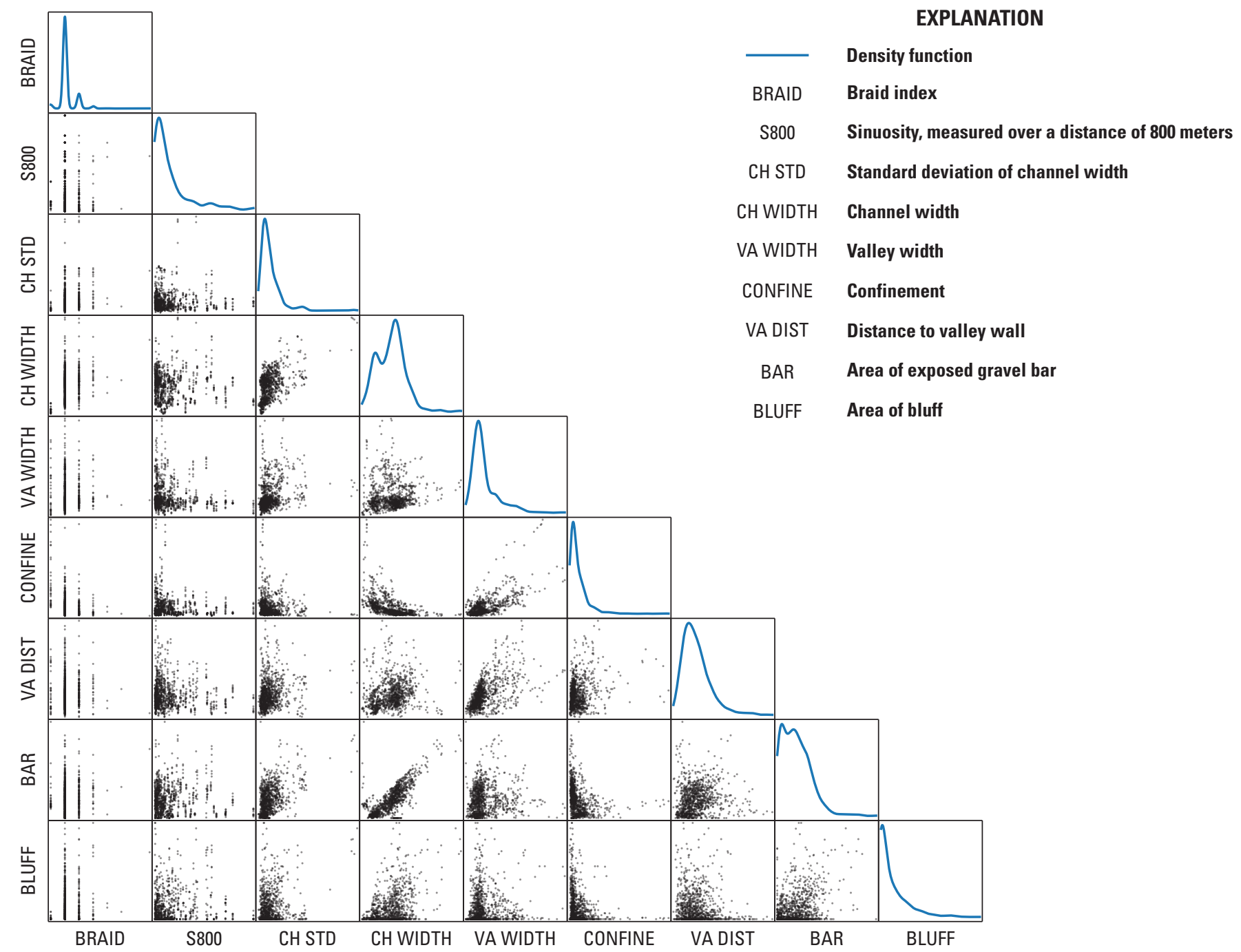

Figure 25. Bivariate scatter and frequency plots of nine geomorphic variables determined from analysis of imagery for the Buffalo River, 2010. 


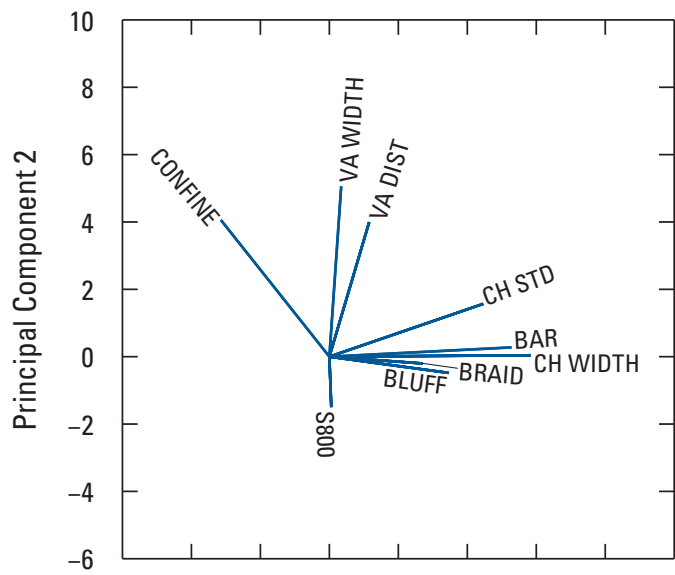

\begin{tabular}{|c|c|c|c|}
\hline \multicolumn{4}{|c|}{ EXPLANATION } \\
\hline BRAID & Braid index & VA WIDTH & Valley width \\
\hline S800 & $\begin{array}{l}\text { Sinuosity, measured over } \\
\text { a distanceof } 800 \text { meters }\end{array}$ & CONFINE & Confinement \\
\hline CH STD & $\begin{array}{l}\text { Standard deviation of } \\
\text { channel width }\end{array}$ & VA DIST & $\begin{array}{l}\text { Distance to valley wall } \\
\text { Area of exposed gravel bar }\end{array}$ \\
\hline H WIDTH & Channel width & BLUFF & Area of bluff \\
\hline
\end{tabular}
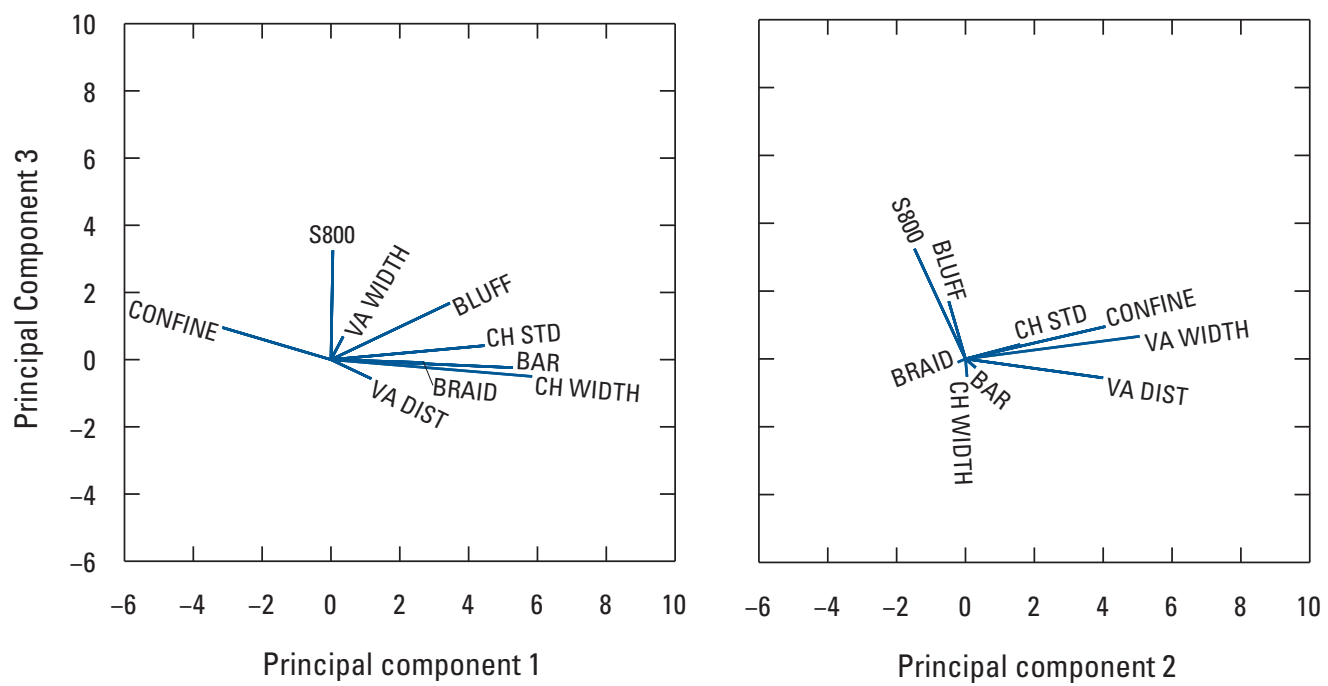

Figure 26. Principal component analysis of standardized geomorphic variables for the Buffalo River. 


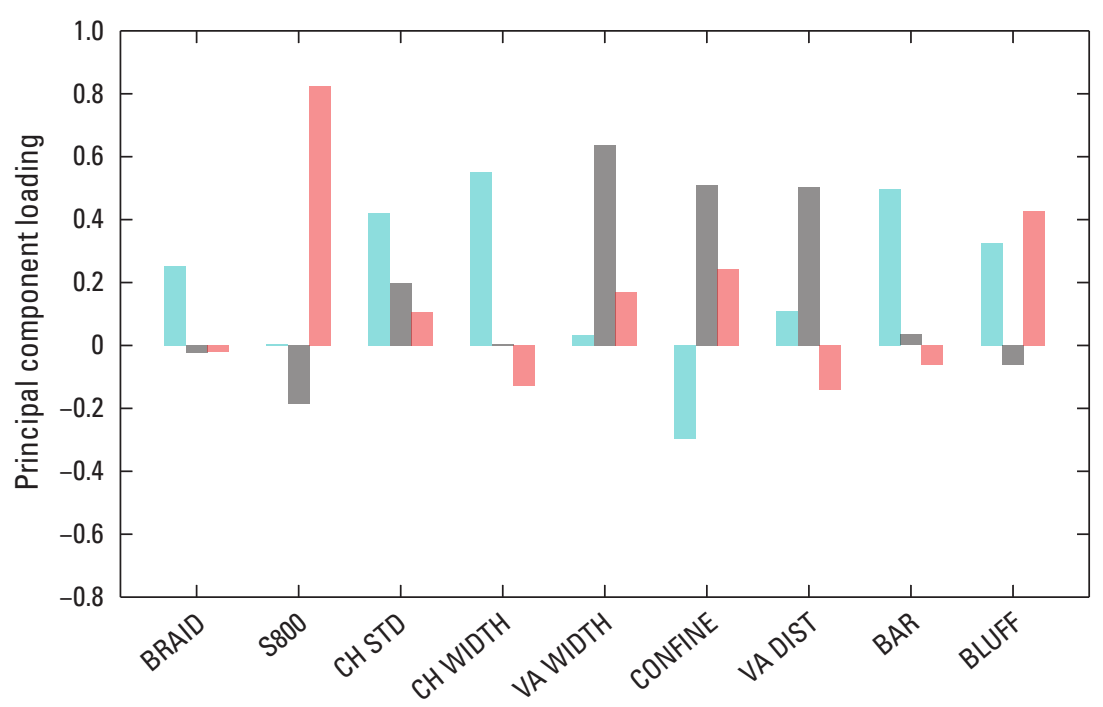

Geomorphic variables

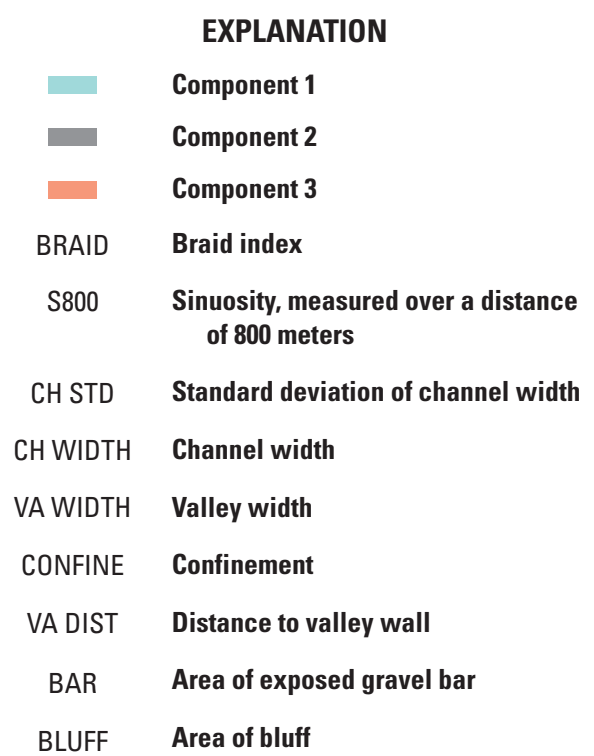

Figure 27. Loading of geomorphic variables on each principal component for the Buffalo River. [BRAID, Braid index; S800, sinuosity measured over a distance of 800 meters; CH STD, standard deviation of channel width; CH WIDTH, channel width; VA WIDTH, valley width; CONFINE, confinement; VA DIST, distance to valley wall; BAR, area of exposed gravel bar; BLUFF, area of bluff]

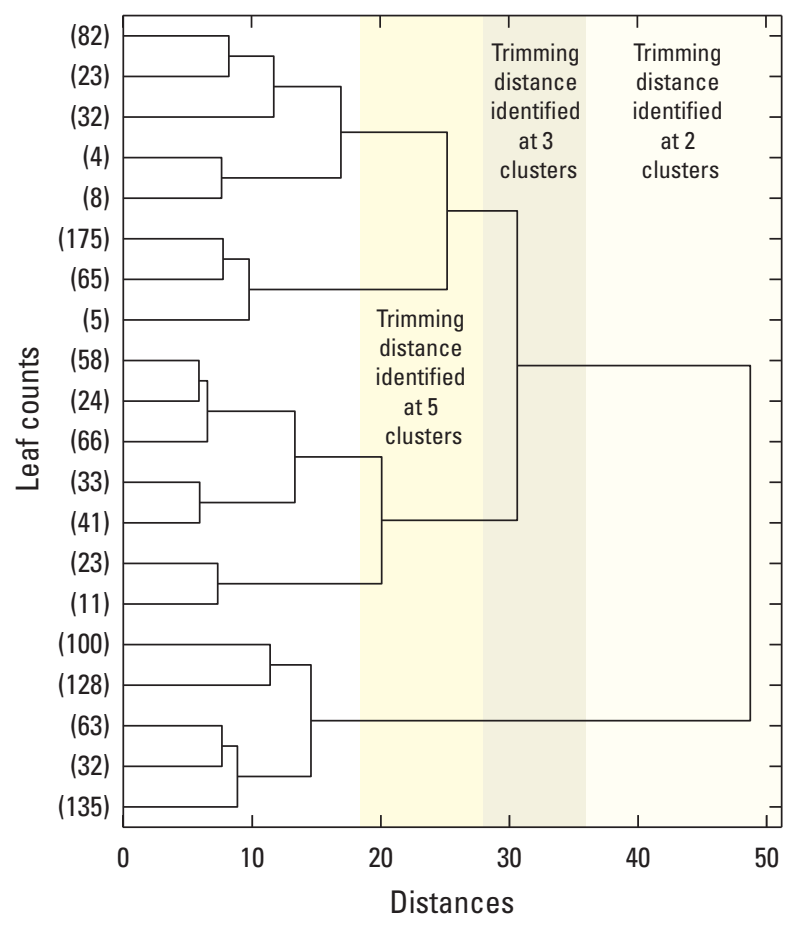

Figure 28. Dendrogram of Buffalo River geomorphic characteristics, with trimming distances identified at two, three, and five clusters. 


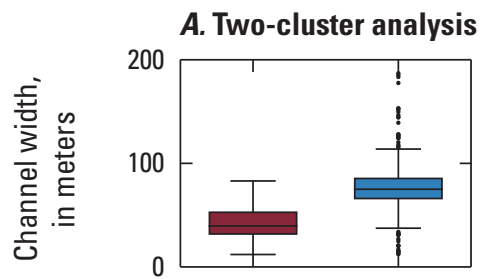

\section{B. Three-cluster analysis}

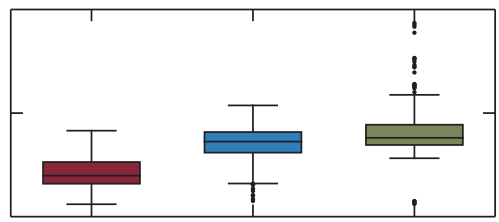

\section{EXPLANATION}
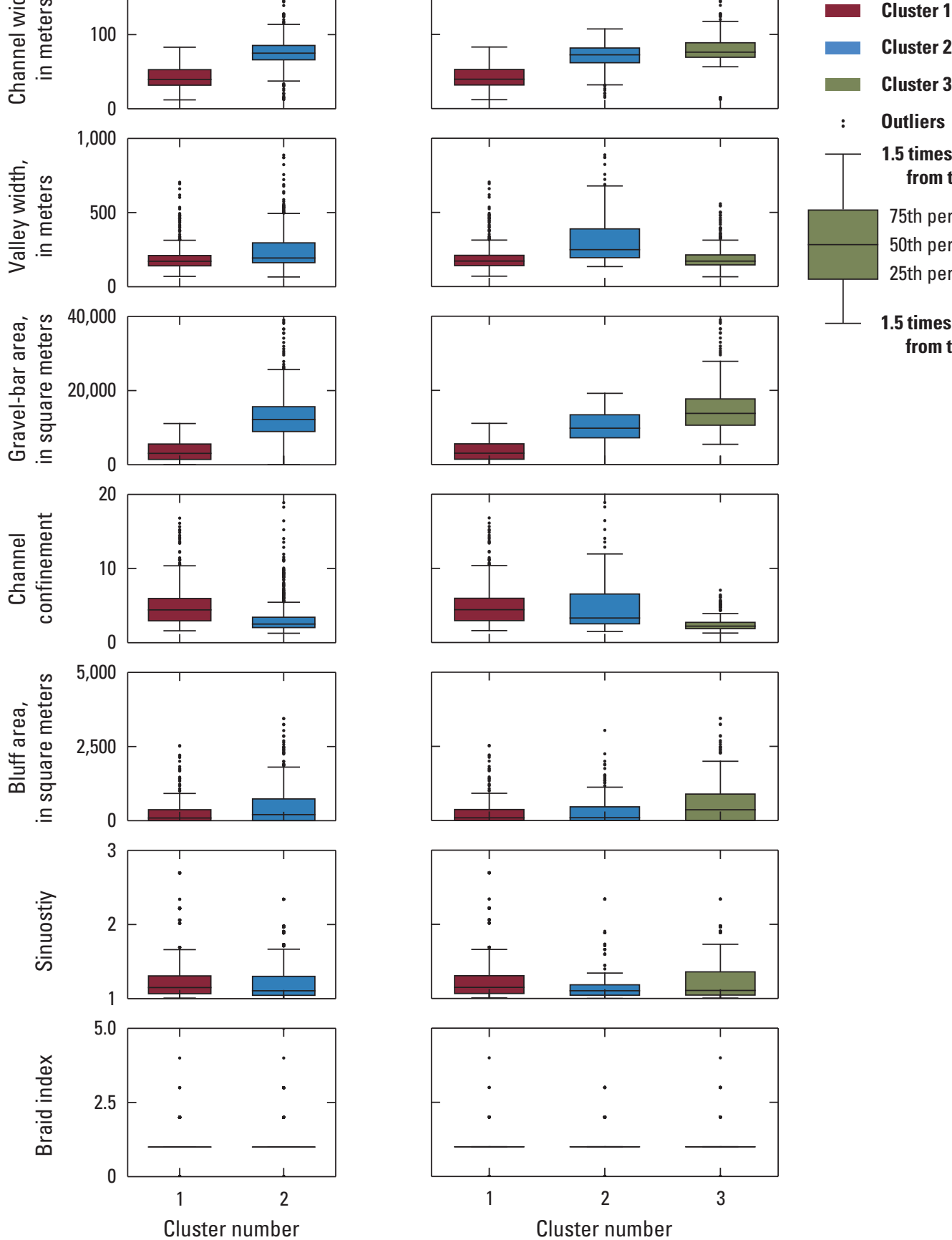

Figure 29. Results of Buffalo River hierarchical clustering. $A$, Two-cluster analysis; and $B$, three-cluster analysis. Clustering analysis was performed using three variables: channel width, valley width, and gravel-bar area. 

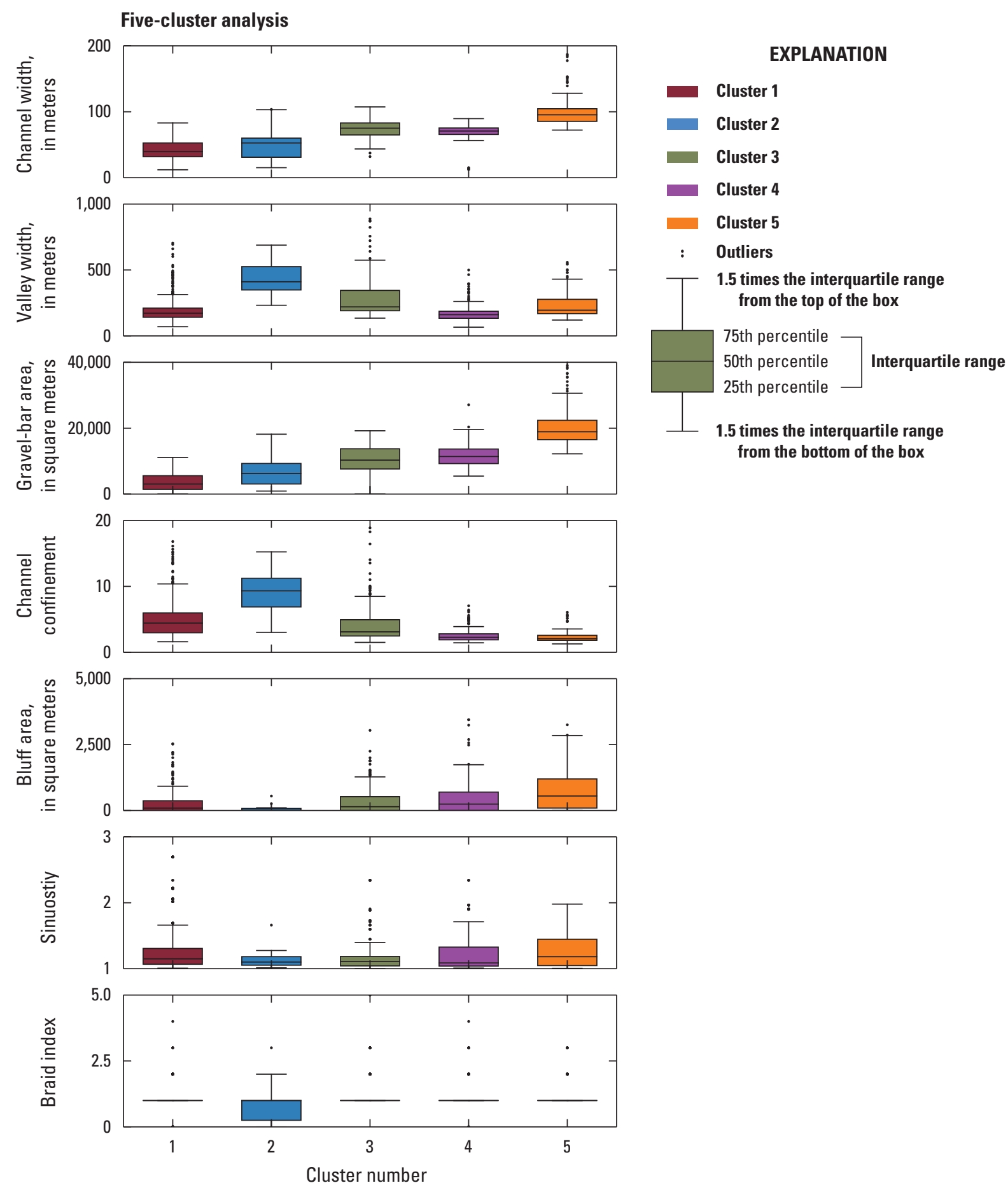

Figure 30. Results of Buffalo River hierarchical clustering for five clusters. Clustering analysis was performed using three variables: channel width, valley width, and gravel-bar area. 

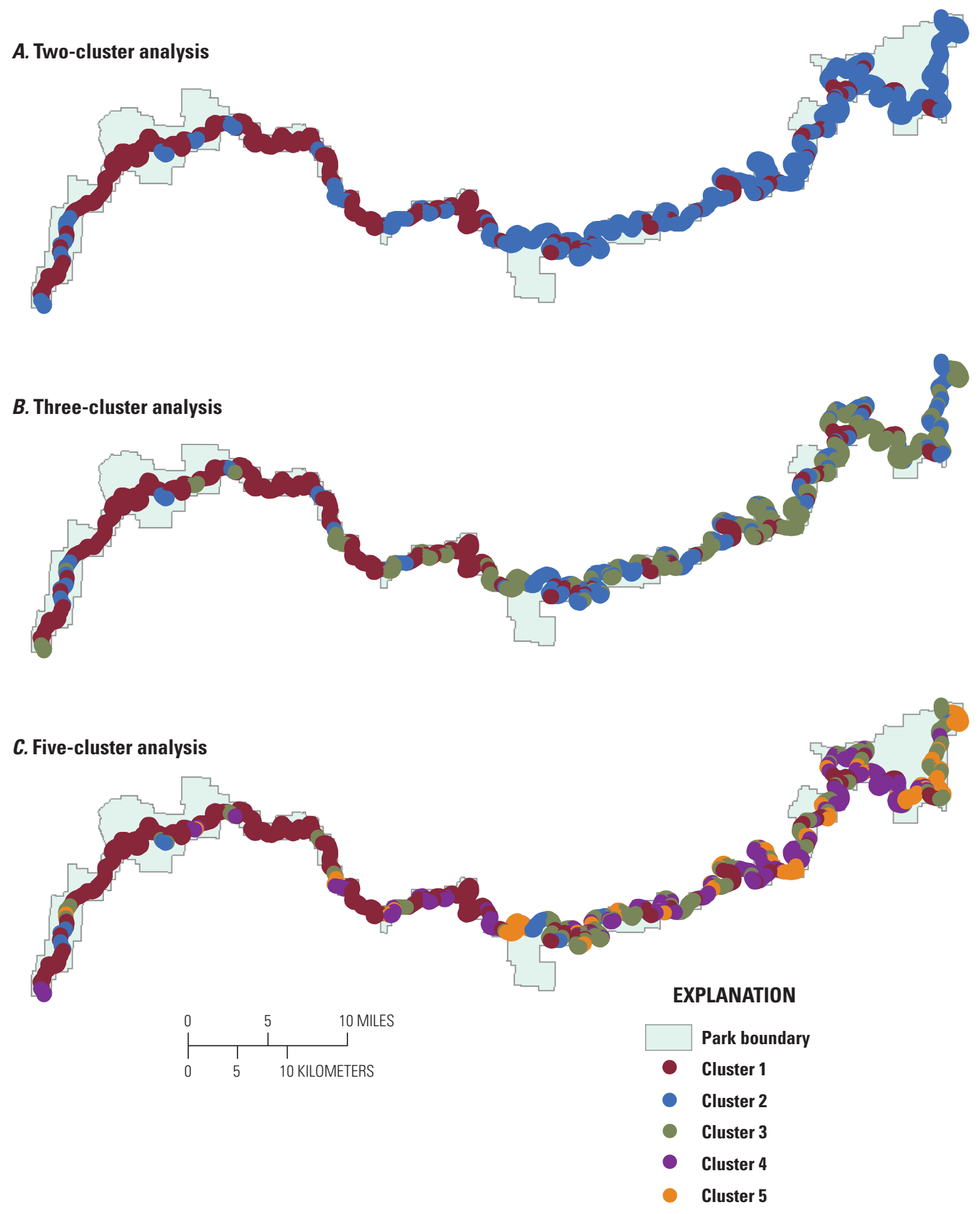

Figure 31. Hierarchical clustering results for the Buffalo River. $A$, Two clusters; $B$, three clusters; and $C$, five clusters. 


\section{Gravel-Bar Inventory}

The objective of this section is to document the longitudinal distribution of gravel storage along the main stem river systems in OZAR and BUFF, and to evaluate trends in distribution of gravel bars through time as observed from available aerial imagery.

\section{Ozark National Scenic Riverways Gravel-Bar Inventory}

On the Current River, there is a general increase in gravel-bar area in the downstream direction during the period of the analysis (fig. 32). The trend is most pronounced in the 2 most recent years of analysis (2010 and 2014), where there is a marked increase in gravel storage in downstream reaches, especially in the vicinity of Mill Creek (fig. 33). In the first 2 years of analysis (1992 and 1996), the period initially considered by Jacobson and Gran (1999), there is more variability in the upper $70+\mathrm{km}$ of the river system. In recent years, this section of river has become more stable, as illustrated by the limited changes in gravel-bar area. As compared to the segment ${ }^{2}$ upstream from the Jacks Fork, there is greater interyear variability in the downstream segment of the Current River.
On the Jacks Fork, there is a less-defined temporal trend (fig. 34). Results of the gravel-bar inventory show more persistent zones of accumulation and no evidence of progressive downstream movement or accumulation of gravel (fig. 35). In general, there is more gravel downstream from Leatherwood Creek, where valley width increases and the channel is less confined (fig. 16).

\section{Buffalo National River Gravel-Bar Inventory}

In the Buffalo River, there is generally less gravel storage within the active channel in the segment of river upstream from the Little Buffalo River (fig. 36). This trend is most pronounced for the analysis of 2006, 2010, and 2013, where there is little change in gravel-bar area measured in this segment of river (fig. 37). In the 2 earliest years of analysis (1982 and 2000), the greatest normalized gravel-bar area was documented in the vicinity of Richland Creek. Since the mid-2000s, the apex of gravel storage has been documented farther downstream, and in the most recent year of analysis (2013) there is greater longitudinal variability in gravel-bar storage in the section of river downstream from Tomahawk Creek.

\footnotetext{
${ }^{2}$ We use "segment" to denote lengths of river having similar flow regime and valley-scale geologic constraints on form and process (Frissell and others, 1986).
}

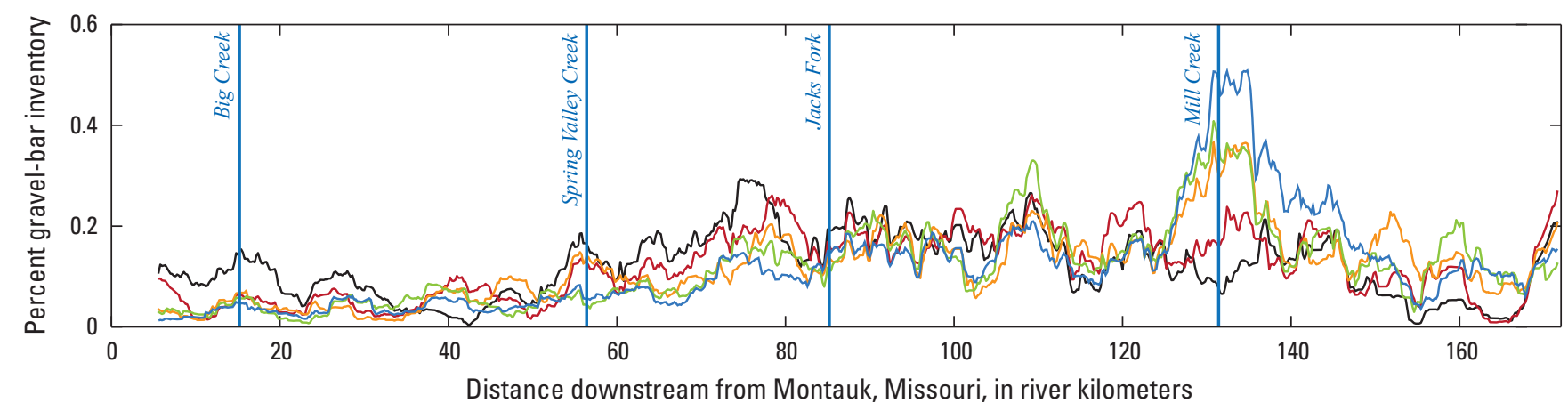

EXPLANATION

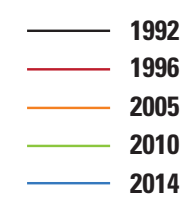

Figure 32. Normalized gravel bar area along the Current River as measured using five series of aerial images (1992-2014). Select tributaries (represented by dashed vertical lines) are included for reference. 

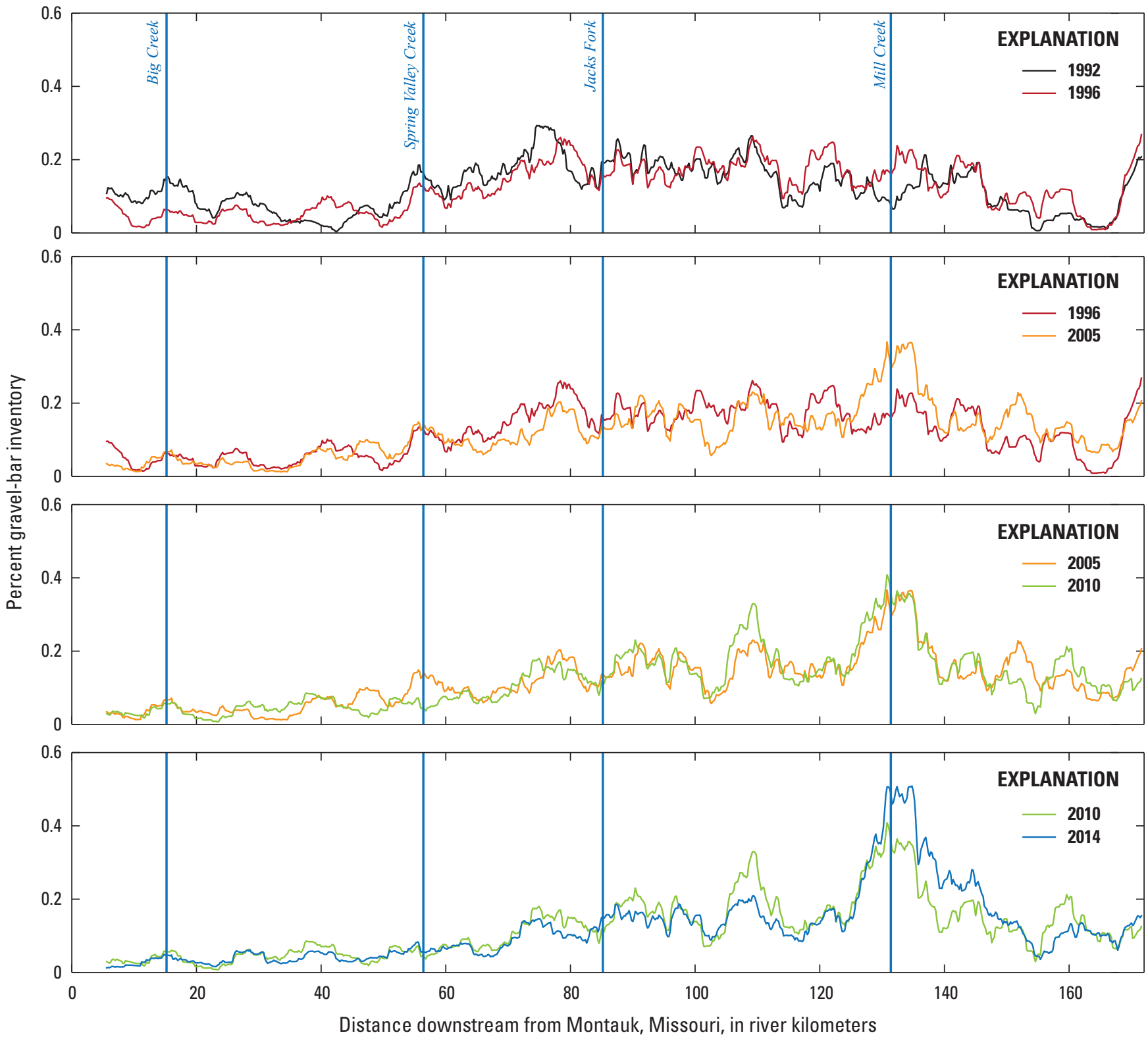

Figure 33. Normalized gravel-bar area along the Current River for progressive pairs of aerial images (1992-2014).Select tributaries are represented by dashed vertical lines. 


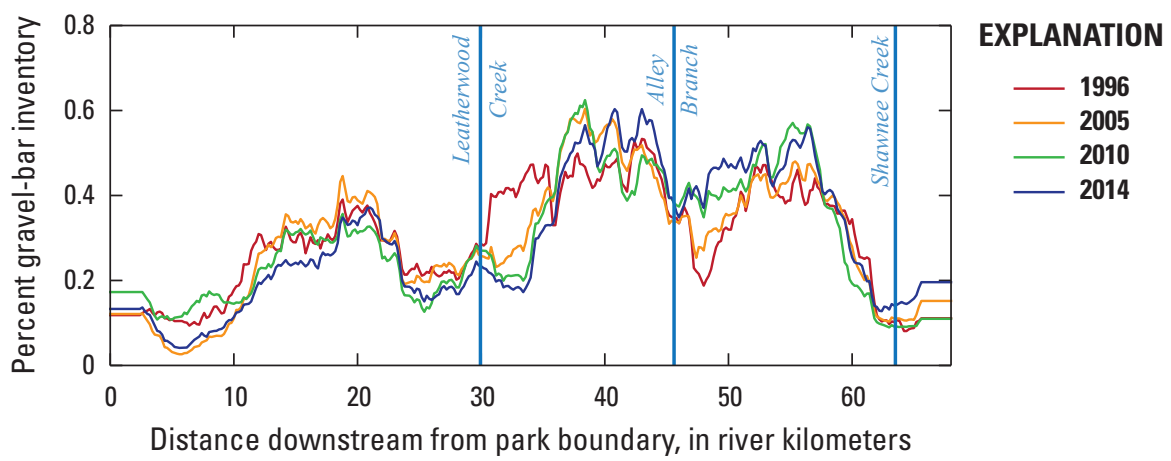

Figure 34. Normalized gravel-bar area along the Jacks Fork as measured using four series of aerial images (1996-2014). Select tributaries are represented by dashed vertical lines.

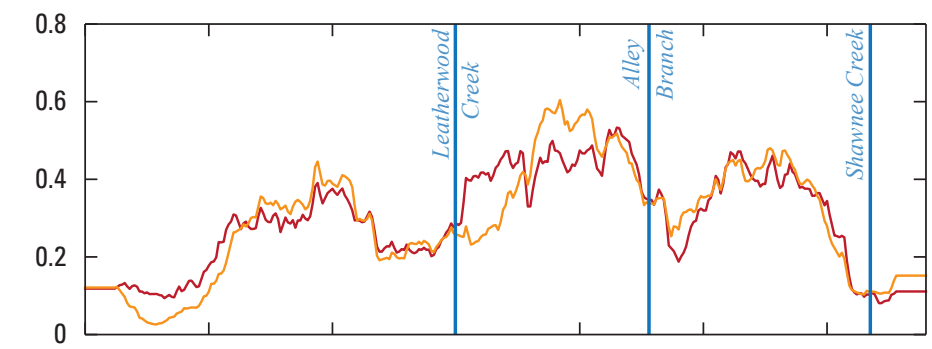

EXPLANATION

$-1996$

2005

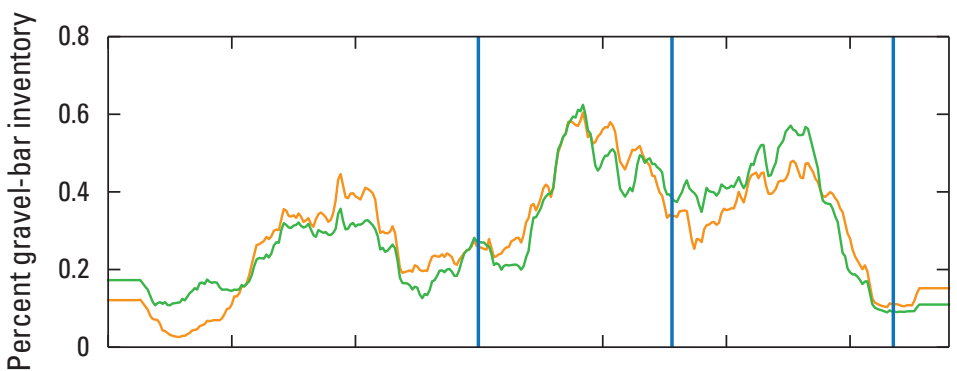

EXPLANATION

- 2005

2010

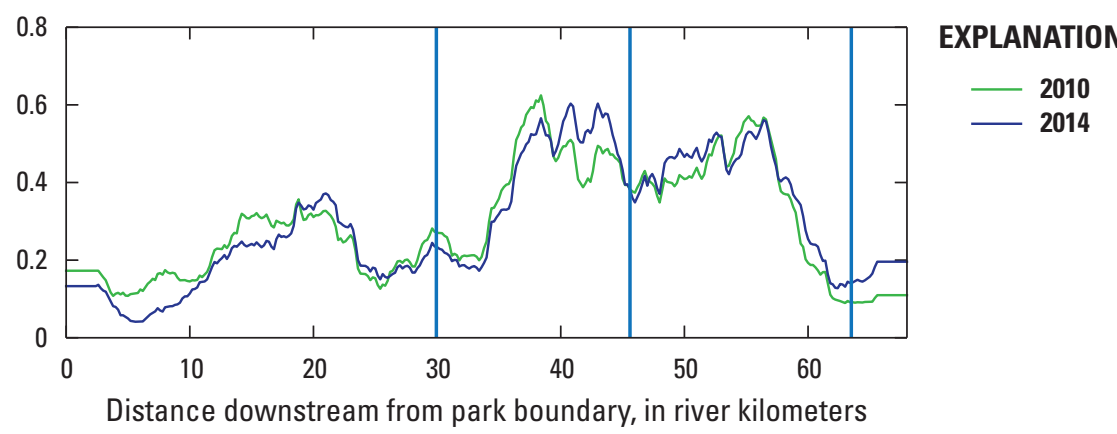

Figure 35. Normalized gravel-bar area along the Jacks Fork for progressive pairs of aerial images (1996-2014). Select tributaries are represented by dashed vertical lines. 


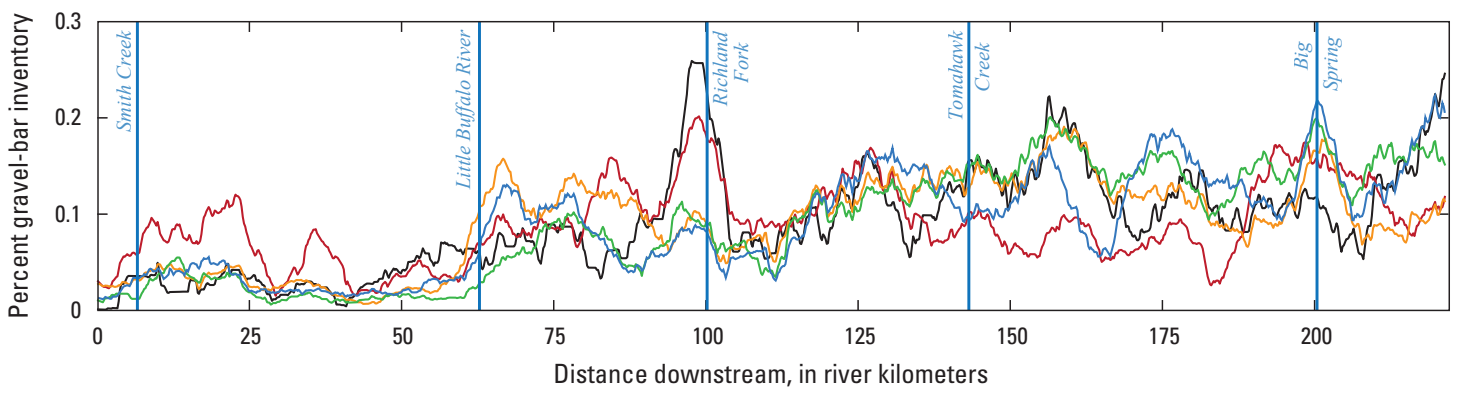

EXPLANATION

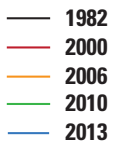

Figure 36. Normalized gravel-bar area along the Buffalo River as measured using five series of aerial images (1982-2013). Select tributaries are represented by dashed vertical lines.
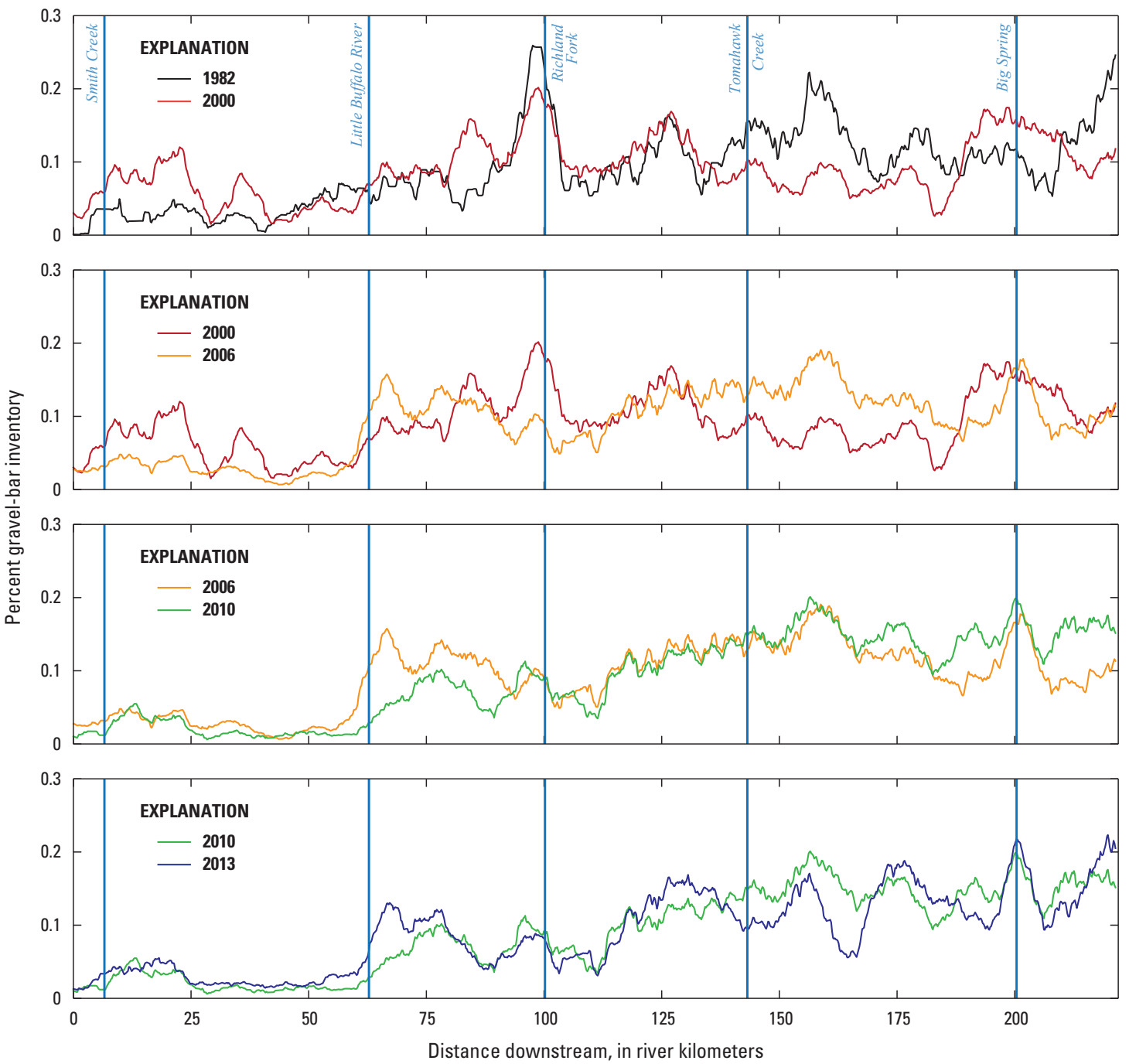

Figure 37. Normalized gravel-bar area along the Buffalo River for progressive pairs of aerial images (1982-2013). Select tributaries are represented by dashed vertical lines. 


\section{Discussion}

The character and distribution of gravel bars are affected by processes operating at three spatial scales. At the broadest spatial scale, the basin scale, longitudinal patterns in distribution and storage of bed material load may reflect (1) differences in rate of sediment delivery from tributaries and hillslopes, (2) the legacy of historic land use in the river basin, and (3) geologic controls that influence channel planform. At the segment scale, previous studies have identified patterns in gravel distribution that emerge from hydraulic interactions between the channel and valley wall. Jacobson (1995) coined the phrase "disturbance reach" to emphasize the role of ecological disturbances in these reaches, as juxtaposed with so-called "stable" reaches that lacked extensive lateral channel movement. The term disturbance reach referred to what had originally been called sedimentation zones by Saucier (1983), which are reaches with relatively high sediment storage that are characterized by active erosion and deposition of coarse sediment in bars. The scale and spacing of disturbance and stable reaches (hundreds to thousands of meters) was observed to occur at a scale that was different from channel units or habitat features, such as riffle-pool spacing (hundreds to thousands of meters). Finally, at the reach scale, bed load transport and storage reflect local channel geometry and hydraulics, with depositional features such as lateral, midchannel, and point bars storing gravel.

River response to sediment disturbance may include geometric and textural adjustments (Fryirs, 2017). Geometric dimensions of river change may include vertical (bed) adjustments, lateral (planform) adjustments, or a wholesale change (fundamental transition in river form, or state). The analysis presented here was based on remotely sensed data, and thus enabled assessment of channel sediment storage within the active channel from a planform perspective but did not include information on vertical adjustment. Presumably some changes in vertical adjustment (local changes in bed elevation) accompanied the patterns in aggradation and degradation shown through the bar analysis. Previous work (Jacobson, 1995) documents changes in bed elevation related to gravel waves, but it is beyond the scope of this report to reassess or discuss the complexities of how the planform and vertical are related. Similarly, although the gravel-bar inventory provided evidence of geometric adjustments, there is insufficient information to quantitatively assess textural changes over the spatial and temporal scale of the present analysis. Nonetheless, one may infer the changes in the longitudinal distribution and storage of coarse sediments in the Jacks Fork, Current, and Buffalo Rivers have been accompanied by some adjustments in the grain size and sorting of bed material. There are insufficient historic data to support spatially extensive analysis of grain size, but future efforts to evaluate aquatic habitat may benefit from a more rigorous assessment of patterns and changes in caliber of bed material.

The signature of historic land-use practices on streams of the Ozark Plateaus has been evaluated in a series of complementary studies that include analyses of aerial imagery, streamgage records, flood plain stratigraphy, and oral histories (Jacobson, 1995; Jacobson and Primm, 1997; Jacobson and Pugh, 1997; Jacobson and Gran, 1999; Jacobson and others, 2001). The general conclusion from these previous studies was that the clearing of valley bottoms and forests in the late 1800 s and early 1900 s led to an increase in gravel delivery to low-order streams, thus resulting in upstream extension of drainages and the widening of low-order tributaries. These landscape disturbances contributed additional sediment to Ozark streams and it was hypothesized these coarse sediments formed wave-like accumulations, possibly leading to increased channel instability, bank erosion, and the degradation of aquatic habitat. The present study indicates a general trend of decreasing sediment within the active channel in upstream reaches of the three rivers considered, and increasing sediments stored farther downstream, thus lending support to the hypothesis of sediment waves migrating through the channel.

The data presented here support earlier interpretations of sediment waves, but also indicate features that remain unexplained. Over the measured extent of all three rivers, the spatial distribution of gravel is similar during the time periods compiled (figs. 32-37). The general downstream increase in quantity and variability is punctuated by persistent accumulations at some locations (for example, river kilometers 80, 110, and 130 on the Current River; 20, 35-50, and 65-80 on the Jacks Fork; and 65, 95, and 200 on the Buffalo River). Notably, unlike the sedimentation zones noted by Church (1983) on rivers in British Columbia, many of the persistent accumulations on the three Ozarks rivers are not explicitly associated with tributaries. Accumulations at the persistent locations vary with time, whereas transient accumulations are apparent between the main peaks.

These observations lead to a general conceptual model of gravel waves migrating through the channel network and preferentially accumulating at some locations. The three elements of the conceptual model are (1) transient migration of sediment pulses through channel network, (2) accumulations that are controlled (in part) by the topological structure of that channel network such that some waves may become augmented at channel junctions, and (3) reach-scale factors, like bedrock-controlled interaction of the channel with bluffs, that favor persistent zones of accumulation. 
The hypothesis that network topology controls how sediment waves augment or diminish in the Ozarks was introduced by Jacobson (1995) to explain variable patterns of aggradation at streamgages. In an extension, a simple model of translation and growth of gravel waves on the Current River based on gravel routing through the channel network predicted a distribution of gravel on the main stem that was consistent with the distribution of gravel mapped in 1992; running that model into the future predicted additional downstream growth and translation of gravel bars (Jacobson and Gran, 1999). Key assumptions of the model were (1) gravel was delivered to headwaters tributaries in the Current River over a short timeframe, and (2) gravel pulses then translated downstream as coherent waves without diffusive deformation. In reality, subsequent spatially and temporally distributed sediment-delivery events probably contributed to the initial delivery event during the 1880-1920 timeframe, resulting in substantially more complexity in the distribution pattern expected along main stem rivers as additional waves interacted with earlier waves. A complex history of sediment delivery and transport, combined with the potential for reach-scale interactions with bedrock bluffs, could result in the apparent mix of systematic and random accumulations in the three rivers (figs. 32-37). Further research is needed to explicitly consider the natural and land-use factors affecting local patterns in deposition and storage of sediment.

The conceptual model for the Ozarks is consistent with conceptual and computational sediment routing models developed to explain sediment distributions in other landscapes (Benda and others, 2004; Czuba and Foufoula-Georgiou, 2014, 2015). As explained by Gran and Czuba (2017), these models address the tradeoffs in processes that promote advection of sediment pulses (that is, downstream translation of a sediment wave) and dispersion (that is, flattening and extension of the sediment wave). Although it has been argued that transport of most sediment pulses will be dispersive (Lisle and others, 1997; Gran and Czuba, 2017), situations exist wherein coherent waves may persist or translate, at least in appearance. For example, the longitudinal distributions of gravel bars documented in this report show examples of waves that persist at locations and have varied in amplitude with time (for example, river kilometers 95 and 160 on the Buffalo River, fig. 36).

Perturbations to boundary conditions (namely hydrologic and sediment regimes) that exert a first-order control on stream geomorphology may be characterized as discrete events ("pulse") versus longer-duration ("press") disturbances (Lake, 2000; Fryirs, 2017). Although the initial riparian disturbance and timber cutting of the late 19th and early 20th centuries in the Ozarks might be considered a pulse disturbance, evolving land-use practices of the past century - including timber management, range land, and road construction - may be viewed more as press disturbances across the landscape (Jacobson, 2004). Evidence of moderately increased sediment supplies constitutes a perturbation in flux boundary conditions - notably sediment regime. Collectively, analyses to date (2020) indicate that rivers in the Ozarks have accommodated sediment through textural, vertical, and lateral adjustments, but have retained a general form (or "style") rather than undergoing large-scale transformation (or "state transition").

Since the last years of aerial imagery analyzed as part of this study (2014 in OZAR and 2013 in BUFF), there have been two significant flood events across the Ozarks. In late December 2015 through early January 2016, heavy rainfall resulted in major flooding in portions of the study area (Holmes and others, 2016). This event was followed by extreme flooding in late April and early May of 2017 (Heimann and others, 2018). In this later event, excessive rainfall over much of the southern Midwest resulted in peak-of-record streamflow in numerous rivers across the Ozarks Plateau, including those measured by the streamgages at Jacks Fork at Eminence, Mo. (07066000) and Current River at Van Buren, Mo. (07067000) on April 30, 2017. The annual exceedance probability on the Jacks Fork at Eminence, Mo., streamgage was 0.2 percent, or an estimated 500-year recurrence interval. The annual exceedance probability for the Current River at Van Buren, Mo., streamgage was 0.47 percent, corresponding to a 213 -year recurrence interval. These extreme events exceeded the National Weather Service flood stage by 15 and 17 feet on the Jacks Fork and Current River, respectively (Heimann and others, 2018), and resulted in notable geomorphic change throughout portions of the study area. The effects of these two large-scale pulse disturbances are not covered in the present study, but the data presented here may serve as a reference for subsequent studies seeking to evaluate the extent and magnitude of channel change in the Ozarks in response to the rare floods, and the capacity of river channels to accommodate or adapt to increasing large floods forecast in coming decades.

The result may also provide some guidance for assessing and restoring native mussel populations. The observation that upper reaches of each of the three rivers appear to have less gravel accumulation and less variability of accumulation with time indicates that the channel is likely more stable and less susceptible to transport events that could dislodge and displace mussels. Accumulation of gravel in downstream reaches may be associated in part with increased bed disturbance and therefore decreased habitat suitability for sedentary mussels. This hypothesis is subject to the caveat that gravel deposition in disturbance zones may create patches of highly suitable habitat in terms of sediment size and hydroperiod. For example, disturbance zones in Ozarks streams have been associated with increased fish-habitat diversity owing to geomorphic dynamics that create overflow channels, backwaters, and forewaters (Rabeni and Jacobson, 1993). Similarly, lateral channel movement in disturbance reaches can create a diverse mosaic of benthic habitats with varying stability, thereby providing more opportunity for suitably stable mussel habitat compared to less complex reaches. 


\section{Summary}

The primary objective of the study was to characterize geomorphic patterns that affect channel stability and rates of geomorphic change in the Ozark National Scenic Riverways (OZAR) and Buffalo National River (BUFF). The data summarized here provide a baseline characterization of the physical attributes of the riverine ecosystems in two national parks in order to inform understanding and management of aquatic habitat. The study utilized publicly available, remotely sensed data and consisted of two components: a basin-scale channel classification and a longitudinal inventory of gravel bars. Three river systems were evaluated: Jacks Fork and Current River in OZAR, and the main stem Buffalo River in BUFF.

For the basin-scale channel classification, exploratory statistical analyses were performed using nine geomorphic variables (channel width, standard deviation in channel width, valley width, distance to valley wall, confinement, bar area, bluff area, braid index, and sinuosity). Each metric was quantified along the length of the river system at 200-meter intervals. A clustering analysis was performed for each river using a subset of variables, resulting in 2 to 5 distinct geomorphic classes depending on criteria used for determining number of clusters. Longitudinal patterns in clusters vary for each river system but reflect a combination of landscape factors including valley width, influence of tributaries, and lithology.

A longitudinal inventory of gravel bars was conducted by quantifying the area of gravel bars for a series of imagery in each park. In OZAR, five time periods were analyzed, with the earliest being 1992 and most recent being 2014. In BUFF, five series of aerial imagery were also analyzed, ranging from 1982 to 2013. The analysis indicated a general decrease in storage in upstream reaches of each river evaluated, accompanied by a general increase in storage farther downstream. Local patterns in gravel-bar area are associated with longitudinal patterns in geomorphic setting, such as valley geometry and channel width, that affect depositional patterns and sediment storage at the reach scale.

Results of this study may be used to inform understanding of the distribution and availability of aquatic habitat in OZAR and BUFF. Additionally, results may be integrated with ongoing inventories of aquatic organisms to relate geomorphic patterns to the distribution of native freshwater mussels and other aquatic species of interest within the parks. The synthesis of physical and biological data could advance understanding of physical habitat dynamics that may inform restoration and management of aquatic habitat and infrastructure.

\section{References Cited}

Benda, L.E.E., Poff, N.L., Miller, D., Dunne, T., Reeves, G., Pess, G., and Pollock, M., 2004, The network dynamics hypothesis-How channel networks structure riverine habitats: Bioscience, v. 54, no. 5, p. 413-427. [Also available at https://doi.org/ 10.1641/0006-3568(2004)054[0413:TNDHHC]2.0.CO;2.]

Bretz, J.H., 1965, Geomorphic history of the Ozarks of Missouri-State of Missouri, Dept. of Business and Administration v. XLI. Division of Geological Survey and Water Resources, $137 \mathrm{p}$.

Church, M.J., 1983, Pattern of instability in a wandering gravel bed channel, in Collinson, J.D., and Lewin, J., eds., Modern and ancient fluvial systems v. 6: Oxford, United Kingdom, Blackwell, p. 169-180. [Also available at https://doi.org/10.1002/9781444303773.ch13.]

Clubb, F.J., Bookhagen, B., and Rheinwalt, A., 2019, Clustering river profiles to classify geomorphic domains: Journal of Geophysical Research. Earth Surface, v. 124, no. 6, p. 1417-1439. [Also available at https://doi.org/10.1029/2019JF005025.]

Czuba, J.A., and Foufoula-Georgiou, E., 2014, A network-based framework for identifying potential synchronizations and amplifications of sediment delivery in river basins: Water Resources Research, v. 50, no. 5, p. 3826-3851. [Also available at https://doi.org/10.1002/2013WR014227.]

Czuba, J.A., and Foufoula-Georgiou, E., 2015, Dynamic connectivity in a fluvial network for identifying hotspots of geomorphic change: Water Resources Research, v. 51, no. 3, p. 1401-1421. [Also available at https://doi.org/10.1002/2014WR016139.]

Elliott, C.M., and Jacobson, R.B., 2014, Stream classification of the Apalachicola-Chattahoochee-Flint River System to support modeling of aquatic habitat response to climate change: U.S. Geological Survey Scientific Investigations Report 2014-5080, 79 p. [Also available at https://doi.org/10.3133/sir20145080.]

Erwin, S.O., 2020, Stream classification and gravel bar inventory for Buffalo National River and Ozark National Scenic Riverways, 1982-2014: U.S. Geological Survey data release, https://doi.org/10.5066/P9ZGVTOP.

Frissell, C.A., Liss, W.J., Warren, C.E., and Hurley, M.D., 1986, A hierarchical framework for stream habitat classification-Viewing streams in a watershed context: Environmental Management, v. 10, no. 2, p. 199-214. [Also available at https://doi.org/10.1007/BF01867358.] 
Fryirs, K.A., 2017, River sensitivity-A lost foundation concept in fluvial geomorphology: Earth Surface Processes and Landforms, v. 42, no. 1, p. 55-70. [Also available at https://doi.org/10.1002/esp.3940.]

Gran, K.B., and Czuba, J.A., 2017, Sediment pulse evolution and the role of network structure: Geomorphology, v. 277, p. 17-30. [Also available at https://doi.org/10.1016/j.geomorph.2015.12.015.]

Heimann, D.C., Holmes, R.R., Jr., and Harris, T.E., 2018, Flooding in the southern Midwestern United States, April-May 2017: U.S. Geological Survey Open-File Report 2018-1004, 36 p. [Also available at https://doi.org/10.3133/ofr20181004.]

Holmes, R.R., Jr., Koenig, T.A., Rydlund, P.H., Jr., and Heimann, D.C., 2016, Examination of flood characteristics at selected streamgages in the Meramec River Basin, eastern Missouri, December 2015-January 2016: U.S. Geological Survey Open-File Report 2016-1140, 7 p. [Also available at https://doi.org/10.3133/ofr20161140.]

Hornbach, D.J., 2001, Macrohabitat factors influencing the distribution of naiads in the St. Croix River, Minnesota and Wisconsin, USA, chap. 12 of Bauer, G., and Wächtler, K., eds., Ecology and evolution of the freshwater mussels Unionoida: Springer, p. 213-230.

Hughes, M.L., McDowell, P.F., and Marcus, W.A., 2006, Accuracy assessment of georectified aerial photographs - Implications for measuring lateral channel movement in a GIS: Geomorphology, v. 74 , no. 1-4, p. 1-16. [Also available at https://doi.org/10.1016/j.geomorph.2005.07.001.]

Jacobson, R.B., 1995, Spatial controls on patterns of land-use induced stream disturbance at the drainage-basin scale-An example from gravel-bed streams of the Ozark Plateaus, Missouri: Geophysical Monograph Series, v. 89, p. 219-239. [Also available at https://doi.org/10.1029/GM089p0219.]

Jacobson, R.B., 2004, Watershed sustainability—Downstream effects of timber harvest in the Ozarks of Missouri, chap. 6 of Flader, S.J., eds., Toward sustainability for Missouri forests: U.S. Department of Agriculture Forest Service North Central Research Station, General Technical Publication NC-239, p. 106-128.

Jacobson, R.B., Elliott, C.M., and Huhmann, B.L., 2010, Development of a channel classification to evaluate potential for cottonwood restoration, lower segments of the Middle Missouri River, South Dakota and Nebraska: U.S. Geological Survey Scientific Investigations Report 2010-5208, 38 p. [Also available at https://doi.org/10.3133/sir20105208.]
Jacobson, R.B., Femmer, S.R., and McKenney, R.A., 2001, Land-use changes and the physical habitat of streams - A review with emphasis on studies within the U.S. Geological Survey Federal-State Cooperative Program: U.S. Geological Survey Circular 1175, 63 p. [Also available at https://doi.org/10.3133/cir1175.]

Jacobson, R.B., and Gran, K.B., 1999, Gravel sediment routing from widespread, low-intensity landscape disturbance, Current River Basin, Missouri: Earth Surface Processes and Landforms, v. 24, no. 10, p. 897-917. [Also available at https://doi.org/10.1002/(SICI)10969837(199909)24:10\%3C897:AID-ESP18\%3E3.0.CO;2-6.]

Jacobson, R.B., and Primm, A.T., 1997, Historical land-use changes and potential effects on stream disturbance in the Ozark Plateaus, Missouri: U.S. Geological Survey Water-Supply Paper 2484, 85 p.

Jacobson, R.B., and Pugh, A.L., 1997, Riparian vegetation controls on the spatial pattern of stream-channel instability, Little Piney Creek, Missouri: U.S. Geological Survey Water-Supply Paper 2494, 33 p. [Also available at https://doi.org/10.3133/wsp2494.]

Keen-Zebert, A., Hudson, M.R., Shepherd, S.L., and Thaler, E.A., 2017, The effect of lithology on valley width, terrace distribution, and bedload provenance in a tectonically stable catchment with flat-lying stratigraphy: Earth Surface Processes and Landforms, v. 42 , no. 10 , p. $1573-1587$. [Also available at https://doi.org/10.1002/esp.4116.]

Lake, P.S., 2000, Disturbance, patchiness, and diversity in streams: Journal of the North American Benthological Society, v. 19 , no. 4, p. 573-592. [Also available at https://doi.org/10.2307/1468118.]

Leopold, L.B., Wolman, M.G., Wolman, M.G., and Wolman, M.G., 1957, River channel patterns-Braided, meandering, and straight: U.S. Geological Survey Professional Paper 282-B, p. 39-85.

Lisle, T.E., Pizzuto, J.E., Ikeda, H., Iseya, F., and Kodama, Y., 1997, Evolution of a sediment wave in an experimental channel: Water Resources Research, v. 33, no. 8, p. 1971-1981. [Also available at https://doi.org/10.1029/97WR01180.]

Martin, D.J., and Pavlowsky, R.T., 2011, Spatial patterns of channel instability along an Ozark river, southwest Missouri: Physical Geography, v. 32, no. 5, p. 445-468. [Also available at https://doi.org/10.2747/0272-3646.32.5.445.] 
Martin, D.J., Pavlowsky, R.T., and Harden, C.P., 2016, Reach-scale characterization of large woody debris in a low-gradient, Midwestern U.S.A. river system: Geomorphology, v. 262, p. 91-100. [Also available at https://doi.org/10.1016/j.geomorph.2016.03.005.]

Missouri Geological Survey, 2015, Compilation of geologic mapping at 1:100,000 scale, Missouri: accessed January 2021 at https://msdis-archive.missouri.edu/archive/ Missouri_Vector_Data/Geological_Geophysical/.

National Park Service, 2020, National Park Service visitor use statistics: accessed October 2020 at https://irma.nps.gov/STATS/Reports/National.

Owen, M.R., Pavlowsky, R.T., and Womble, P.J., 2011, Historical disturbance and contemporary floodplain development along an Ozark river, southwest Missouri: Physical Geography, v. 32, no. 5, p. 423-444. [Also available at https://doi.org/10.2747/0272-3646.32.5.423.]

Panfil, M.S., and Jacobson, R.B., 2001, Relations among geology, physiography, land use, and stream habitat conditions in the Buffalo and Current River systems, Missouri and Arkansas: U.S. Geological Survey Biological Science Report 2001-0005, 111 p. [Also available at https://pubs.er.usgs.gov/publication/bsr010005.]

Rabeni, C.F., and Jacobson, R.B., 1993, The importance of fluvial hydraulics to fish habitat restoration in low gradient alluvial streams: Freshwater Biology, v. 29, no. 2, p. 211-220. [Also available at https://doi.org/10.1111/j.1365-2427.1993.tb00758.x.]

Roux, C., Alber, A., Bertrand, M., Vaudor, L., and Piégay, H., 2015, "FluvialCorridor"-A new ArcGIS toolbox package for multiscale riverscape exploration: Geomorphology, v. 242, p. 29-37. [Also available at https://doi.org/10.1016/j.geomorph.2014.04.018.]

Saucier, R.T., 1983, Historic changes in Current River meander regime, in Elliott, C.M., ed., River meandering: American Society of Civil Engineers, p. 180-190.
Sims, P.K., Kisvarsanyi, E.B., and Morey, G., 1987, Geology and metallogeny of Archean and Proterozoic basement terranes in the northern midcontinent, USA; an overview: U.S. Geological Survey Bulletin 1815, 51 p. [Also available at https://doi.org/10.3133/b1815.]

Stoeser, D.B., Green, G.N., Morath, L.C., Heran, W.D., Wilson, A.B., Moore, D.W., and Van Gosen, B.S., 2005, Preliminary integrated geologic map databases for the United States - Central States-Montana, Wyoming, Colorado, New Mexico, Kansas, Oklahoma, Texas, Missouri, Arkansas, and Louisiana: U.S. Geological Survey Open-File Report 2005-1351. [Also available at https://doi.org/10.3133/ofr20051351.]

Strayer, D.L., 2008, Freshwater mussel ecology-A multifactor approach to distribution and abundance. University of California Press, 216 p.

Thaler, E., and Covington, M.D., 2016, The influence of sandstone caprock material on bedrock channel steepness within a tectonically passive setting -Buffalo National River Basin, Arkansas, USA: Journal of Geophysical Research. Earth Surface, v. 121, no. 9, p. 1635-1650. [Also available at https://doi.org/10.1002/2015JF003771.]

Tiegs, S.D., and Pohl, M., 2005, Planform channel dynamics of the lower Colorado River-1976-2000: Geomorphology, v. 69, no. 1-4, p. 14-27. [Also available at https://doi.org/10.1016/j.geomorph.2004.12.002.]

U.S. Department of Agriculture, [n.d.], Geospatial data gateway: accessed January 2014 at https://datagateway.nrcs.usda.gov/.

U.S. Geological Survey, [n.d.], Earth Explorer: accessed January 2014 at https://earthexplorer.usgs.gov/.

U.S. Geological Survey, 2018, National Geospatial Program: The National Map, accessed November 2014 at https://www.usgs.gov/core-science-systems/nationalgeospatial-program/national-map.

Ward, J.H., Jr., 1963, Hierarchical grouping to optimize an objective function: Journal of the American Statistical Association, v. 58, no. 301, p. 236-244. [Also available at https://doi.org/10.1080/01621459.1963.10500845.] 
For more information about this publication, contact: Director, USGS Columbia Environmental Research Center 4200 New Haven Road

Columbia, M0 65201

573-875-5399

For additional information, visit: https://www.usgs.gov/centers/cerc

Publishing support provided by the U.S. Geological Survey Science Publishing Network, Rolla and Sacramento Publishing Service Centers 
